\title{
Reductions, Reductive Alkylations, and Intramolecular Cyclizations of Acyl Silanes with Samarium Diiodide or Tributyltin Hydride
}

\author{
Tsung-Hsun Chuang, J im-Min Fang,* Weir-Torn J iaang, and Yeun-Min Tsai* \\ Department of Chemistry, National Taiwan University, Taipe 106, Taiwan, Republic of China
}

Received November 7, $1995^{\circledR}$

\begin{abstract}
A series of acyl silanes including aliphatic-, aromatic-, and bis-acyl silanes, as well as the acyl silanes bearing other substituents such as a bromine atom and alkenyl, succinimide, and carbonyl groups, were prepared, and their reactions with samarium diiodide or tributylstannane were studied. The reactions of acyl silanes occurred in various manners such as reductions, reductive alkylations, intramolecular radical cyclizations, pinacol couplings, aldol reactions, and Tishchenko reactions, depending on the nature of substrates and reaction conditions. Acyl silanes were generally reduced to give the corresponding $\alpha$-silyl al cohols without transfer of silyl groups. Intramolecular radical cyclizations of 5-hexenoyl silanes and 1-silyl-1,5-pentanedione were realized to give $\alpha$-silyl cyclopentanols and 1,2-cyclopentanediol derivatives, respectively. On treatment with samarium diiodide in tetrahydrofuran, 1-(trimethylsilyl)-1,6-hexanedione underwent a pinacol coupling reaction in the presence of t-BuOH, whereas it underwent a Tishchenko reaction in the presence of $\mathrm{MeOH}$. The Tishchenko reaction of 1-silyl-1,5-pentanedione gave a $\delta$-silyl- $\delta$-lactone. On treating with samarium diiodide, 1-(trimethylsilyl)-1,5-hexanedione and 1,5-bis(trimethylsilyl)-1,6-hexanedione, underwent, respectively, intramolecular aldol reactions.
\end{abstract}

\section{Introduction}

Acyl silanes are carbonyl derivatives exhibiting unusual chemical and physical properties. ${ }^{1}$ Acyl silanes, though sensitive to light and to basic media, behave frequently as typical ketones such as giving $\alpha$-silyl alcohols on treatment with $\mathrm{LiAlH}_{4}^{2}$ or borane ${ }^{3}$ and giving hydrazones on treatment with hydrazines. ${ }^{4}$ An acyl silane can be considered as the synthetic equivalent of an aldehyde of which hydrogen atom is substituted with a bulky silyl group. For example, addition of organolithium ${ }^{5}$ or Grignard reagent ${ }^{6}$ to an acyl silane gives the secondary alcohol as a consequence of the Brook rearrangement ${ }^{7}$ to form a strong $\mathrm{O}-\mathrm{Si}$ bond. The reaction of an acyl silane with an $\alpha$-lithio sulfone ${ }^{8}$ gives silyl enol ethers via the Brook rearrangement and extrusion of the sulfonyl group. Metalation of acyl silanes with lithium diisopropylamide ${ }^{9}$ or reduction of $\alpha$-bromoacyl silane with zinc (Reformatsky reaction) ${ }^{10}$ give the corresponding enolates, which undergo aldol reactions with aldehydes in diastereoselective manners. Aldol reactions between silyl enol ethers of acylsilanes and acetals are also realized with the catalysis of Lewis acids. ${ }^{11}$ Aromatic acyl silanes function as acyl anion equivalents on treating with fluoride ion and are trapped with electrophiles..$^{12,13}$

${ }^{\otimes}$ Abstract published in Advance ACS Abstracts, February 1, 1996.

(1) For reviews on the chemistry, synthesis, and physical properties of acylsilanes, see: (a) Page, P. C. B.; Klair, S. S.; Rosenthal, S. Chem. Soc. Rev. 1990, 19, 147. (b) Ricci, A.; Degl'Innocenti, A. Synthesis 1989, 647. (c) Cirillo, P. F.; Panek, J. S. Org. Prep. Proc. Int. 1992, 24, 553.

(2) Brook, A. G. Adv. Organomet. Chem. 1968, 7, 96.

(3) Buynak, J. D.; Strickland, J . B.; Hurd, T.; Phan, A. J . Chem. Soc., Chem. Commun. 1989, 89.

(4) (a) Yoshida, J .-i.; I toh, M.; Matsunaga, S.-i.; I soe, S. J . Org. Chem. 1992, 57, 4877. (b) Bartoli, G.; Bosco, M.; Dalpozzo, R.; Marcantoni, E. Tetrahedron Lett. 1990, 31, 6935.

(5) For a representive example, see: Reich, H. J .; Eisenhart, E. K.; Olsen, R. E.; Kelly, M. J . J . Am. Chem. Soc. 1986, 108, 7791.

(6) For a representive example, see: Kuwajima, I.; Enda, J . J . Am. Chem. Soc. 1985, 107, 5495.

(7) Brook, A. G. Acc. Chem. Res. 1974, 7, 77

(8) Reich, H. J .; Eisenhart, E. K. J . Org. Chem. 1984, 49, 5282.

(9) Schinzer, D. Synthesis 1989, 179.

(10) Horiuchi, Y.; Taniguchi, M.; Oshima, K.; Utimoto, K. Tetrahedron Lett. 1995, 36, 5353.
2-Alkenoyl silanes are generally used as the acceptors in Michael reactions, ${ }^{14}$ Diels-Alder reactions, ${ }^{15}$ and [3 +2 ] annulations. ${ }^{16}$ Intramolecular addition of a carbon radical to acyl silane is facilitated by an irreversible radical Brook rearrangement. ${ }^{17}$

In recent years, one-electron reductions of carbonyls with $\mathrm{Sml}_{2}$ to produce samarium ketyl radical anions have generated a lot of attentions. ${ }^{18}$ These ketyl radical intermediates are found useful in the formation of carbon-carbon bonds via addition to multiple bonds ${ }^{19}$ or Barbier-type of coupling reactions with halides. ${ }^{20}$ When employed intramolecularly, these methods can be used to construct cyclic structures. ${ }^{21}$ Similarly, stannyl radicals generated from tributyltin hydride and carbonyl compounds have also been used to generate O-stannyl ketyls. ${ }^{22}$ These ketyls were shown to add intramolecularly to ol efins or carbonyls quite successfully. As part of our interest in the exploration of the radical reactions of acyl silanes, we have studied the reactions of acyl silanes with $\mathrm{Sml}_{2}$ and tributyltin hydride. Experiments

(11) Ricci, A.; Degl'Innocenti, A; Borselli, G.; Reginato, G. Tetrahe dron Lett. 1987, 28, 4093.

(12) Degl'Innocenti, A.; Pike, S.; Walton, D. R. M.; Seconi, G.; Ricci A.; Fiorenza, M. J . Chem. Soc., Chem. Commun. 1980, 1201.

(13) Schnizer, D.; Heathcock, C. H. Tetrahedron Lett. 1981, 22, 1881.

(14) Danheiser, R. L.; Fink, D. M. Tetrahedron Lett. 1985, 26, 2509.

(15) Reich, H. J .; Kelly, M. J .; Olson, R. E.; Holtan, R. C. Tetrahedron 1983, 39, 949.

(16) Danheiser, R. L.; Fink, D. M. Tetrahedron Lett. 1985, 26, 2513.

(17) (a) Dalton, J . C.; Bourque, R. A. J . Am. Chem. Soc. 1981, 103, 699. (b) Harris, J. M.; Macinnes, I.; Walton, J. C.; Mailard, B. J . J . Organometal. Chem. 1991, 403, C25-C28. (c) Tsai, Y.-M.; Cherng, C.D. Tetrahedron Lett. 1991, 32, 3515. (d) Curran, D. P.; J iang, W.-T.; Palovich, M.; Tsai, Y.-M. Synlett 1993, 403. (e) Tsai, Y.-M.; Tang, K.H.; J iaang, W.-T. Tetrahedron Lett. 1993, 34, 1303. (f) Tsai, Y.-M., Ke, B.-W. J . Chin. Chem. Soc. 1993, 40, 641. (g) Robertson, J .; Burrows, J . N. Tetrahedron Lett. 1994, 35, 3777. (h) Tsai, Y.-M.; Chang, S.-Y. J . Chem. Soc., Chem. Commun. 1995, 981.

(18) For reviews on $\mathrm{Sml}_{2}$, see: (a) Kagan, H. B; Namy, J. L. Tetrahedron 1986, 42, 6573. (b) I nanaga, J.J . Syn. Org. Chem. 1989, 47, 200. (c) Soderquist, J . A. Aldrichim. Acta 1991, 24, 15. (d) Molander, G. A. Chem. Rev. 1992, 92, 29. (e) Brandukova, N. E.; Vygodskii, Y. S.; Vinogradova, S. V. Russ. Chem. Rev. 1994, 63, 345.

(19) For intermolecular ketyl-olefin coupling reactions, see: Ujikawa, O.; Inanaga, J .; Yamaguchi, M.; Tetrahedron Lett. 1989, 30, 2837.

(20) Girard, P.; Namy, J. L.; Kagan, H. B. J . Am. Chem. Soc. 1980, $102,2693$. 
Scheme 1

1.<smiles>CC#CC1(c2ccccc2)SCCCS1</smiles><smiles>C#CCC(C)C(=O)c1ccccc1</smiles>

1

2.

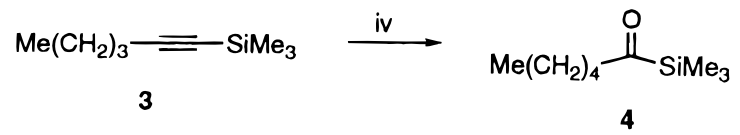

3.

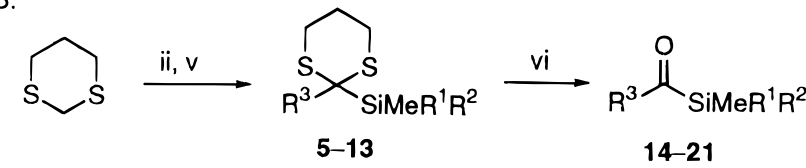

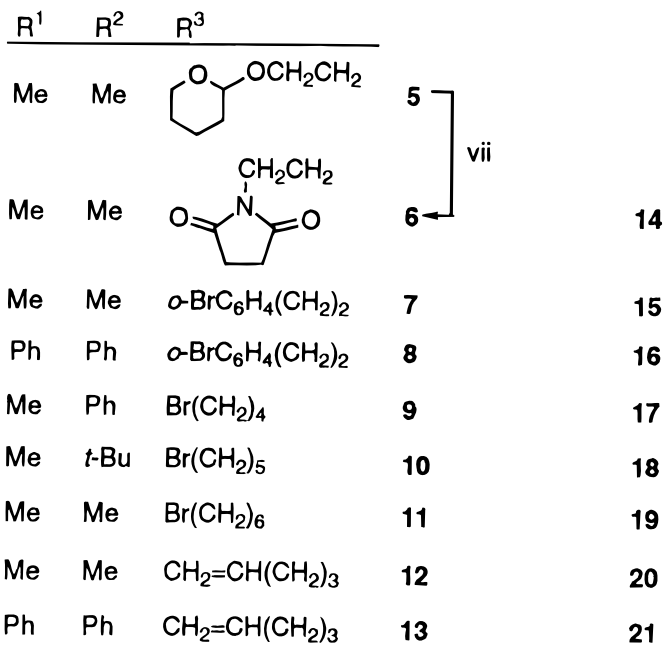

Reagents and conditions: i, $\mathrm{HS}\left(\mathrm{CH}_{2}\right)_{3} \mathrm{SH}$, cat. $\mathrm{BF}_{3} \cdot \mathrm{OEt}_{2}, \mathrm{CHCl}_{3} ; 87 \%$ ii, BuLi, CISiMeR ${ }^{1} R^{2}$, THF; for $1, R^{1}=R^{2}=M e, 98 \%$. iii, $\mathrm{HgO}, \mathrm{HgCl}_{2}$, $\mathrm{MeOH}, \mathrm{H}_{2} \mathrm{O} ; 82 \%$. iv, $\mathrm{Me}_{2} \mathrm{~S} \cdot \mathrm{BH}_{3}, \mathrm{THF} \mathrm{Me}_{3} \mathrm{NO} ; 77 \%$. v, BuLi, R ${ }^{3} \mathrm{X}$. vi, $\mathrm{HgO}, \mathrm{BF}_{3} \cdot \mathrm{OEt}_{2}, \mathrm{THF} / \mathrm{H}_{2} \mathrm{O}$ or $\left(\mathrm{NH}_{4}\right)_{2} \mathrm{Ce}\left(\mathrm{NO}_{3}\right)_{6}, \mathrm{CH}_{3} \mathrm{CN} / \mathrm{H}_{2} \mathrm{O}$. vii, cat. $\mathrm{TsOH}, \mathrm{MeOH}$; succinimide, $\mathrm{Ph}_{3} \mathrm{P}, \mathrm{DEAD}, \mathrm{THF} ; 77 \%$.

are designed to examine the reactivities of the silyl substituted ketyls with various functionalities. The results of these experiments are described in this paper.

\section{Results and Discussion}

Acyl silanes $\mathbf{2}^{23 b}$ and 14-21 were generally prepared from 1,3-dithianes (Scheme 1) according to Brook and Corey's method. ${ }^{23}$ Hexanoyl silane $4^{24}$ was prepared from hydroboration-oxidation of 1-hexynyl silane 3. Preparation of bis-acyl silanes 28-31 (Scheme 2), 5-oxohexanoyl silane 33 (Scheme 3), and formylalkanoyl silanes 37 and 46-48 (Scheme 4) were also illustrated. Hydrolysis of 2-silyl-1,3-dithianes to the corresponding acyl silanes

(21) (a) Molander, G. A.; Kenny, C. Tetrahedron Lett. 1987, 28, 4367. (b) Fevig, T. L.; Elliott, R. L.; Curran, D. P. J . Am. Chem. Soc. 1988, 110, 5064. (c) Molander, G. A.; Mckie, J . A. J . Org. Chem. 1991, 56, 4112.

(22) (a) Beckwith, A. L. J .; Roberts, D. H. J . Am. Chem. Soc. 1986, 108, 5893. (b) Sugawara, T.; Otter, B. A.; Ueda, T. Tetrahedron Lett. 1988, 29, 75. (c) Enholm, E. J .; Burroff, J . A. Tetrahedron Lett. 1992, 33, 1835. (d) Zelechonok, Y.; Silverman, R. B. J . Org. Chem. 1992, 57, 5785. (e) Rawal, V. H.; Krishnamurthy, V.; Fabre, A. Tetrahedron Lett. 1993, 34, 2899. (f) Lee, E.; Tae, J. S.; Chong, Y. H.; Park, Y. C. Tetrahedron Lett. 1994, 35, 129. (g) Hays, D. S.; Fu, G. C. J . Am. Chem. Soc. 1995, 117, 7283. (h) Enholm, E. J .; Kinter, K. S. J. Org. Chem. 1995, 60, 4850 .

(23) (a) Brook, A. G.; Duff, J . M.; J ones, P. F.; Davis, N. R. J . Am. Chem. Soc. 1967, 89, 431. (b) Corey, E. J .; Seebach, D.; F reedman, R. J . Am. Chem. Soc. 1967, 89, 434.

(24) Miller, J. A.; Zweifel, G. Synthesis 1981, 288.
Scheme 2

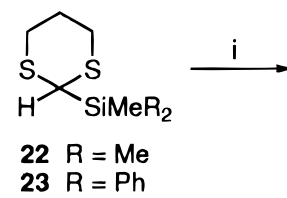<smiles>[R20][SiH2]C1([SiH2])SCCCS1</smiles>

$23 \mathrm{R}=\mathrm{Ph}$

$24 R=M e, n=3$

$25 \mathrm{R}=\mathrm{Ph}, \mathrm{n}=3$

$26 \mathrm{R}=\mathrm{Me}, \mathrm{n}=4$

$27 \mathrm{R}=\mathrm{Me}, \mathrm{n}=6$

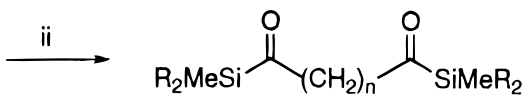

$28 R=M e, n=3$

$29 R=P h, n=3$

$30 \mathrm{R}=\mathrm{Me}, \mathrm{n}=4$

$31 \mathrm{R}=\mathrm{Me}, \mathrm{n}=6$

Reagents and conditions: i, BuLi, $\mathrm{Br}\left(\mathrm{CH}_{2}\right)_{n} \mathrm{Br}\left(0.5\right.$ equiv), THF, $0{ }^{\circ} \mathrm{C}$. ii, $\mathrm{HgO}, \mathrm{BF}_{3} \cdot \mathrm{OEt}_{2}, \mathrm{THF} / \mathrm{H}_{2} \mathrm{O} ; 61-68 \%$ from 22 or 23.

\section{Scheme 3}

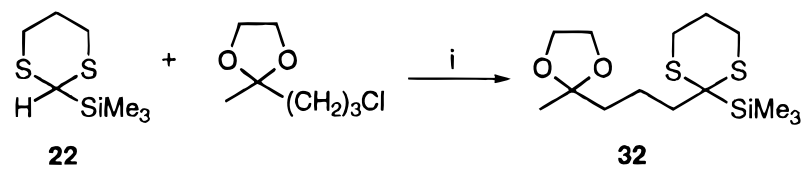

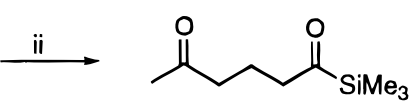

33

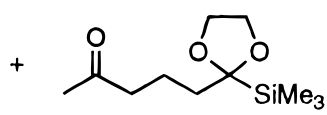

34
Reagents and conditions: i, BuLi, THF, $0{ }^{\circ} \mathrm{C} ; 81 \%$. ii, $\mathrm{HgO}_{3} \mathrm{BF}_{3} \cdot \mathrm{OEt}_{2}$, THF, $\mathrm{H}_{2} \mathrm{O} ; 33,81 \% ; 34,13 \%$; or in acetone, $\mathrm{H}_{2} \mathrm{O} ; 33,91 \%$.

were generally carried out with $\mathrm{HgO}_{\mathrm{BF}} \cdot \mathrm{OEt}_{2}$ in aqueous THF solution. ${ }^{25}$ In addition to the desired acyl silane $33(81 \%)$, a side-product 34 (13\%) was obtained from a transacetalation when $\mathbf{3 2}$ was hydrolyzed in such conditions. The problem was circumvented by hydrolysis in aqueous acetone solution, giving exclusively 33 in 91\% yield. In certain cases, the oxidizing agent $\mathrm{Ce}\left(\mathrm{NH}_{4}\right)_{2}$ $\left(\mathrm{NO}_{3}\right)_{6}{ }^{26}$ or $\mathrm{Phl}\left(\mathrm{CF}_{3} \mathrm{CO}_{2}\right)_{2}{ }^{27}$ were also used for removal of dithiane moiety.

Bis[2-(trialkylsilyl)-1,3-dithianes] 24-27, the precursors of bis-acyl silanes 28-31, were obtained by alkylations of the corresponding 2-(trialkylsilyl)-1,3-dithianes (22 or 23) with appropriate dibromides (0.5 equiv). Alkylation of 2-(trimethylsilyl)-1,3-dithiane (22) with 1,4dibromobutane (1 equiv) gave the dithiane 40, whereas alkylation of 1,3-dithiane with 1,5-dibromopentane $(0.5$ equiv) afforded the bis-dithiane 41. Reaction of the bromide $\mathbf{4 0}$ with 2-lithio-1,3-dithiane and monosilylation of the bis-1,3-dithiane $\mathbf{4 1}$ gave $\mathbf{4 3}$ and 44, which were subsequently hydrolyzed with $\mathrm{HgO} / \mathrm{BF}_{3} \cdot \mathrm{OEt}_{2}$ to give formylalkanoyl silanes 47 (60\%) and 48 (55\%). Formylalkanoyl silane $\mathbf{4 6}$ was synthesized similarly by monosiIylation of the bis-dithiane 39 followed by hydrolysis (70\% from 39). The bis-dithiane 39 was in turn synthesized (55\%) from the reaction of 1,3-propanedithiol with glutaraldehyde. ${ }^{28}$ Sequential transacetalation (cat. $\mathrm{TsOH}$, $\left.\mathrm{Me}_{2} \mathrm{CO}\right)$ and hydrolysis $\left(\mathrm{HgO} / \mathrm{BF}_{3} \cdot \mathrm{OEt}_{2}\right)$ of the dithiane 45, prepared from 22 and 5-bromopentanal ethylene acetal, ${ }^{29}$ also led to the acyl silane 47. 5-Oxopentanoyl

(25) Vedejs, E.; Fuchs, P. L. J . Org. Chem. 1971, 36, 366.

(26) (a) Ho, T.-L; Ho, H. C.; Wong, C. M. J . Chem. Soc., Chem. Commun. 1972, 791. (b) Ho, H. C.; Ho, T.-L; Wong, C. M. Can. J . Chem. 1972, 50, 2718.

(27) Stork, G.; Zhao, K. Tetrahedron Lett. 1989, 30, 287.

(28) Corey, E. J .; Seebach, D. Angew. Chem., Int. Ed. Engl. 1965, 4, 1077.

(29) Kulkarni, S.; Patil, V. D. Heterocycles 1982, 18, 163. 
Scheme 4

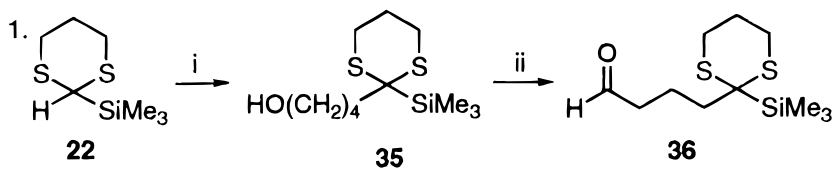<smiles>CC#CCCCCC(C)=O</smiles>
37 38

2.

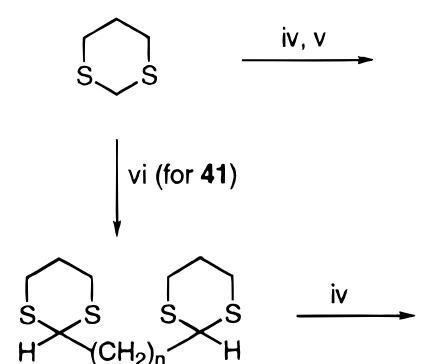

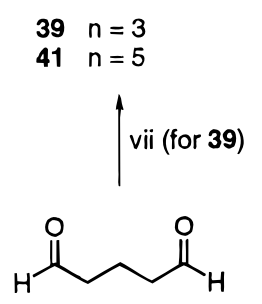

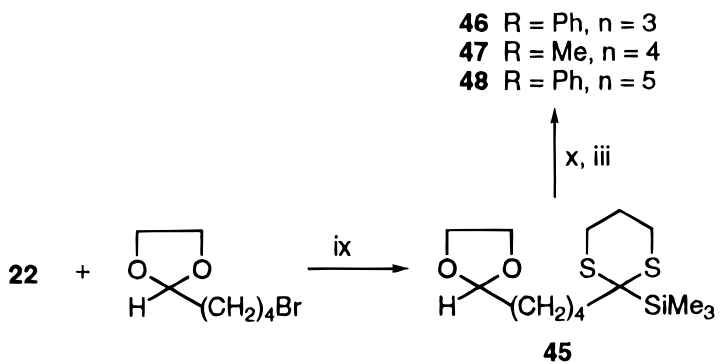

Reagents and conditions: i, LDA (3.3 equiv), $\mathrm{HO}\left(\mathrm{CH}_{2}\right)_{4} \mathrm{Cl}$ (2 equiv), THF; $99 \%$. ii, $\mathrm{PCC}, \mathrm{CH}_{2} \mathrm{Cl}_{2} ; 45 \%$. iii, $\mathrm{HgO}, \mathrm{BF}_{3} \mathrm{OEt}_{2}, \mathrm{THF}^{2} \mathrm{H}_{2} \mathrm{O}$; 37 , $77 \% ; 38,15 \%$. iv, BuLi, $\mathrm{RMe}_{2} \mathrm{SiCl}$, THF. v, BuLi, $\mathrm{Br}\left(\mathrm{CH}_{2}\right)_{4} \mathrm{Br}$ (1 equiv). vi, BuLi, $\mathrm{Br}\left(\mathrm{CH}_{2}\right)_{5} \mathrm{Br}\left(0.5\right.$ equiv), THF; $76 \%$. vii, $\mathrm{HS}\left(\mathrm{CH}_{2}\right)_{3} \mathrm{SH}$, $\mathrm{BF}_{3} \cdot \mathrm{OEt}_{2}, \mathrm{CHCl}_{3} ; 55 \%$. viii, 1,3-dithiane, BuLi, THF. ix, BuLi, THF. $x$, cat. $\mathrm{TsOH}, \mathrm{Me}_{2} \mathrm{CO}$.

silane $\mathbf{3 7}$ was prone to undergo intramol ecular cyclization to give a dihydropyran derivative $\mathbf{3 8}$ if excess of acid existed in the reaction media. ${ }^{30}$

The reaction of benzoyl silane 2 with $\mathrm{Sml}_{2}$ in THF gave simply the reduction product $49(63 \%)^{31}$ even in the absence of proton source. When the reaction was conducted in the presence of HMPA, benzyl phenyl ketone (52) was obtained (30\%) in addition to the silyl alcohol 49 (47\%). Benzal dehyde reacts with $\mathrm{Sml}_{2}$ in the presence of HMPA to give a phenyl-carbonyl coupling product, 4-(1-hydroxybenzyl)benzaldehyde. 32 Acetophenone follows the similar reaction pathway. ${ }^{32}$ However, benzoyl silane did not undergo such phenyl-carbonyl coupling reaction. Treatment of benzoyl silane 2 with $\mathrm{Sml}_{2}$ in the presence of an electrophile such as t-BuOD, allyl bromide, or benzyl bromide gave 49-d (62\%) and alkylated products 50 (84\%) and 51 (91\%). Compound 49-d was

(30) Tsai, Y.-M.; Nieh, H.-C.; Cherng, C.-D. J . Org. Chem. 1992, 57, 7010.

(31) Taniguchi, Y.; Fuji, N.; Makioka, Y.; Takaki, K., Fujiwara, Y. Chem. Lett. 1993, 1165.
Scheme 5

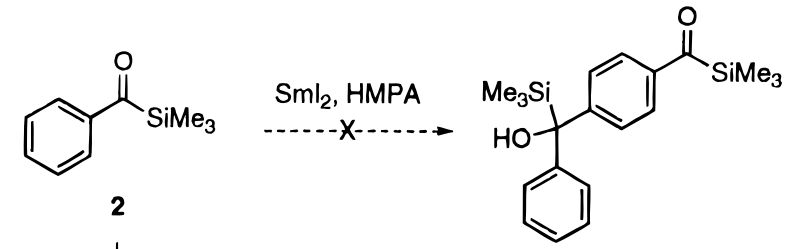
$\downarrow \mathrm{Sml}_{2}$

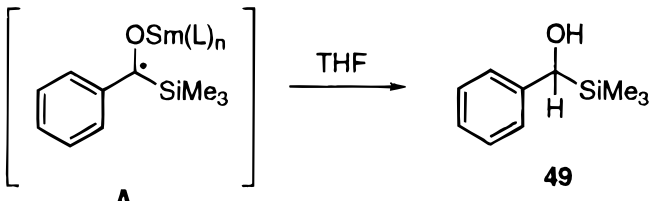
A $\mathrm{Sml}_{2}, \mathrm{HMPA}$<smiles>C[As]1OC1(CC1CCCCC1)c1ccccc1</smiles><smiles>[R]C(O)(c1ccccc1)c1ccccc1</smiles>

B

$49 \mathrm{R}=\mathrm{H}$ 49- $d \mathrm{R}=\mathrm{D}$ $50 \mathrm{R}=\mathrm{CH}_{2}=\mathrm{CHCH}_{2}$ $51 \mathrm{R}=\mathrm{PhCH}_{2}$<smiles>C[Si]1(C)OC([SiH3])(c2ccccc2)C(c2ccccc2)([Si](C)(C)[SiH3])O1</smiles>

C<smiles>[Y]O/C(=C(\SC)c1ccccc1)c1ccccc1</smiles><smiles>O=C(Cc1ccccc1)c1ccccc1</smiles>

52

characterized by a triplet signal occurring at $\delta 69.9(\mathrm{~J}=$ $20 \mathrm{~Hz}$ ) for the carbinyl carbon. The reaction mechanism is shown (Scheme 5). Reduction of the acyl silane by sequential transfers of two electrons from $\mathrm{Sml}_{2}$ (2 equiv) might form an organosamarium $\mathbf{B}^{33}$ to account for the deuteration and alkylations. Benzyl phenyl ketone might be derived from a pinacolate intermediate $\mathbf{C}^{31}$ via se quential transfers of silyl groups and hydrolysis, though the pinacol corresponding to $\mathbf{C}$ was not isolated.

Hexanoyl silane $\mathbf{4}$ was reduced with $\mathrm{Sml}_{2}$ to give the alcohol $\mathbf{5 3}$ (50\%). Selective reductions of acyl silanes $\mathbf{1 4}$ 15, and 16 with $\mathrm{Sml}_{2}$ were realized, giving 54 (50\%), 55 (63\%), and 56 (52\%), respectively, with intact succinimide and bromophenyl moieties. 5-Bromopentanoyl silane $\mathbf{1 7}$ was reduced with $\mathrm{Sml}_{2}$, followed by the intramolecular alkylation, to give exclusively 1-silylcyclopentanol $\mathbf{5 7}$ (47\%). The reaction of 6-bromohexanoyl silane $\mathbf{1 8}$ gave 1-silylcycl ohexanol 58 (45\%) and an open-chain alcohol 59 (17\%). 7-Bromoheptanoyl silane 19 was simply reduced to the corresponding silyl heptanol 60 (55\%),

(32) Shiue, J . S.; Lin, C. C.; Fang, J . M. Tetrahedron Lett. 1993, 34, 335.

(33) (a) Molander, G. A.; Kenny, C. J . Org. Chem. 1991, 56, 1439 (b) Curran, D. P.; Totleben, M. J . Am. Chem. Soc. 1992, 114, 6050. 
Scheme 6
1.

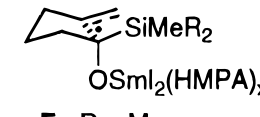

E $\mathrm{R}=\mathrm{Me}$

G $\mathrm{R}=\mathrm{Ph}$
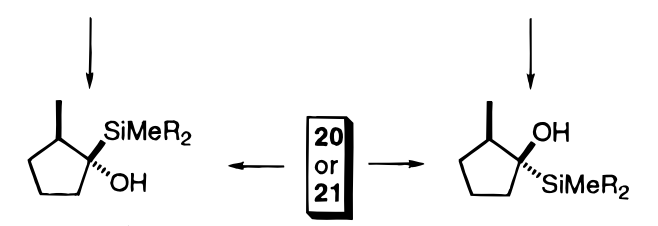

$65 \mathrm{R}=\mathrm{Me}$

66 (cis) $\mathrm{R}=\mathrm{Ph}$

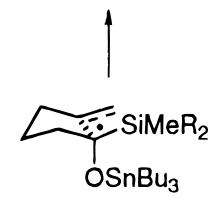

$\mathrm{I} \mathrm{R}=\mathrm{Ph}$

2.
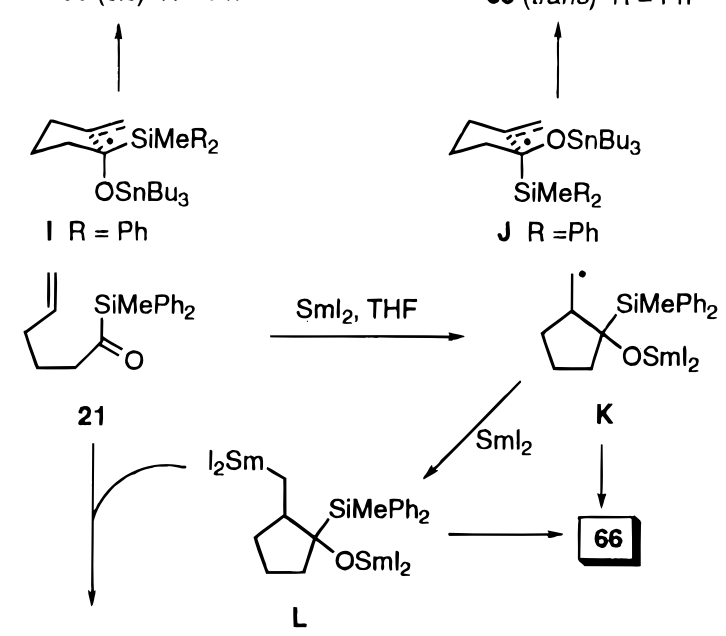

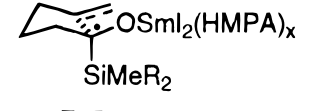

F $\mathrm{R}=\mathrm{Me}$

H R $=\mathrm{Ph}$

66 (trans) $\mathrm{R}=\mathrm{Ph}$

政 
Scheme 8

$$
\begin{aligned}
& 28 \mathrm{R}=\mathrm{Me}, \mathrm{n}=3 \\
& 29 \mathrm{Rh}=3 \\
& 30 \mathrm{R}=\mathrm{Me}, \mathrm{n}=4 \\
& 31 \mathrm{R}=\mathrm{Me}, \mathrm{n=6}
\end{aligned}
$$

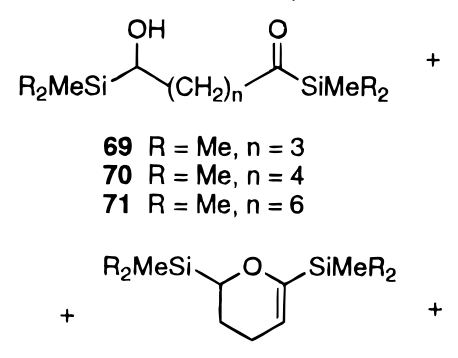

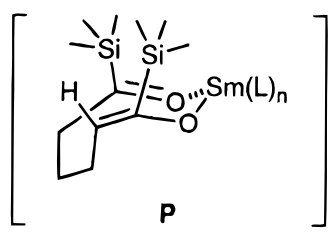

indicated that the chair transition state $\mathbf{I}$, in which the O-stannyl group occupied the axial position, ${ }^{34,35}$ was preferred over J . Diol $\mathbf{6 7}$ was obtained presumably by addition of $\mathbf{2 1}$ with an organosamarium $\mathbf{L}$, which was resulted from further reduction of the radical cyclization intermediate $\mathbf{K}$.

1,8-Bis(trimethylsilyl)-1,8-octanedione (31) was re duced with $\mathrm{Sml}_{2}$ (Scheme 8) to give 8-hydroxy-1,8-bis(trimethylsilyl)octanone (71, one-site reduction, 53\%) and 1,8-bis(trimethylsilyl)-1,8-hexanediol (74, two-site reduction, 36\%). 1,5-Bis(trimethylsilyl)-1,5-pentanedione (28) underwent a one-site reduction with $\mathrm{Sml}_{2}$ (2 equiv), and the product 5-hydroxy-1,5-bis(trimethylsilyl)pentanone (69) further condensed to its dihydropyran form 75. When bis-acyl silane $\mathbf{2 9}$ was treated with tributyltin hydride (2 equiv) in refluxing benzene in the presence of catalytic amount of AIBN, diol 72 was obtained in $12 \%$ yield along with $52 \%$ of dihydropyran 76. Apparently, the silyl substituted O-stannyl ketyl did not add to the acylsilane intramolecularly. This is in sharp contrast to the related intramolecular 1,5-cyclizations of alkyl substituted carbon radicals to acyl silanes. ${ }^{17 c}$

Treatment of 1,6-bis(trimethylsilyl)-1,6-hexanedione (30) with $\mathrm{Sml}_{2}$ (2.5 equiv) afforded mainly an aldol product $77(46 \%)^{36}$ in addition to the one-site reduction product 70 (13\%) and the two-site reduction product 73 (9\%). An NOE study, i.e. irradiation of the resonance of $\mathrm{Me}_{3} \mathrm{Si}$ group (at $\delta-0.05$ ) causing a $20 \% \mathrm{NOE}$ of the resonance of $\alpha$-proton, established that aldol $\mathbf{7 7}$ had the hydroxyl and acyl groups on the same face. In such a

(34) For general radical cyclizations, see: (a) Beckwith, A. L. J . Tetrahedron 1981, 37, 3073. (b) Beckwith, A. L. J .; Schiesser, C. H. Tetrahedron 1985, 41, 3925. (c) Spellmeyer, D. C.; Houk, K. N. J . Org. Chem. 1987, 52, 959. For O-stannyl ketyl related cyclizations, see: (d) Hon, Y.-S.; Sun, P.-P.; Lu, H.-L.; Chang, N.-C. J. Chin. Chem. Soc. 1994, 41, 445. For O-samarium ketyl related cyclizations, see: (e) Molander, G. A.; Mckie, J. A. J . Org. Chem. 1992, 57, 3132. (f) Molander, G. A.; Kenny, C. J . Am. Chem. Soc. 1989, 111, 8236. (g) Molander, G. A.; Mckie, J. A. J . Org. Chem. 1995, 60, 872.

(35) Enholm, E. J .; Prasad, G. Tetrahedron Lett. 1989, 30, 4939.

(36) Some aldol products have been observed in the $\mathrm{Sml}_{2}(\mathrm{Ot}-\mathrm{Bu})$ promoted reaction of 5-oxohexanal, see: Unenishi, J.; Masuda, S.; Wakabayashi, S. Tetrahedron Lett. 1991, 32, 5097.
Scheme 9

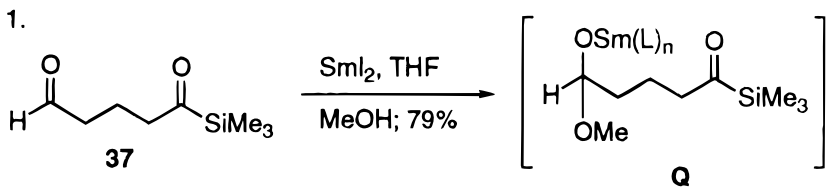

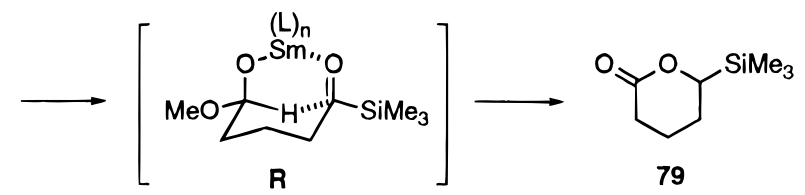<smiles>COC(=O)CCCCCCCCCCCC(=O)OC(C)C</smiles>
47

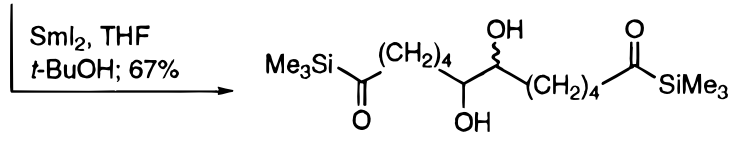

81

case, $\mathrm{Sml}_{2}$ presumably functioned as a Lewis acid to induce the acyl silane to form an (E)-enolate and the subsequent aldol reaction proceeded with a chelate mode P. 37<smiles>CC(=O)CCCC(C)=O</smiles>

33

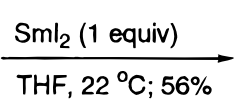<smiles>CSC1(O)CCCC(=O)C1</smiles>

78
1-(Trimethylsilyl)-1,5-hexanedione (33) reacted with $\mathrm{Sml}_{2}$ (eq 1) to give an aldol product 78 (56\%) but no reduction product. No reaction of $\mathbf{3 3}$ occurred in the presence of a proton source $(\mathrm{MeOH}$ or $\mathrm{t}-\mathrm{BuOH})$, and the starting material was recovered. On the other hand, 1-(trimethylsilyl)-1,5-pentanedione (37) reacted with $\mathrm{Sml}_{2}$ (Scheme 9 ) in the presence of $\mathrm{MeOH}$ to give a $\delta$-silyl- $\delta$ lactone 79 (79\%). The reaction was presumably initiated by addition of $\mathrm{MeOH}$ to the aldehyde group to form a hemiacetal with catalysis of $\mathrm{Sml}_{2}$. The intermediate $\mathbf{Q}$ underwent Tishchenko reaction ${ }^{36,38}$ by hydride transfer to the acyl silane $\mathbf{R}$ and led to the observed lactone $\mathbf{7 9 .}$ 1-(Trimethylsilyl)-1,6-hexanedione (47) reacted similarly with $\mathrm{Sml}_{2}$ (Scheme 9) in THF/MeOH to give a methyl ester 80 (62\%). The reaction in THF/t-BuOH gave, however, pinacols $\mathbf{8 1}$ resulted from reductive coupling of the formyl groups. ${ }^{36,39}$

When 1-(dimethylphenylsilyl)-1,5-pentanedione (46) was treated with 1.5 equiv of tributyltin hydride (Scheme 10), cyclization did occur to give monosilylated 1,2cyclopentanediol cis-82 (21\%) and trans-82 (18\%), and cisdiol $\mathbf{8 3}$ (32\%). Diol $\mathbf{8 3}$ was resulted from desilylation of cis-82 during silica gel column chromatographic purification. The stereochemistry of $\mathbf{8 2}$ was determined by comparison with the authentic samples prepared by silylation of the commercially available diols. The reaction of 1-(dimethylphenylsilyl)-1,7-heptanedione (48) with tributyltin hydride (1 equiv) gave only silyl alcohol $\mathbf{8 4}$ in

(37) Heathcock, C. H. in Comprehensive Organic Synthesis; Trost, B. M., Fleming, I., Eds.; Pergamon Press: Oxford, 1991; Vol. 2, Chap. 1.5 .

(38) Evans, D. A.; Hoveyda, A. H. J . Am. Chem. Soc. 1990, 112, 6447 and the references cited therein.

(39) Namy, J . L.; Souppe, J .; Kagan, H. B. Tetrahedron Lett. 1983, 24,765 . 


\section{Scheme 10}
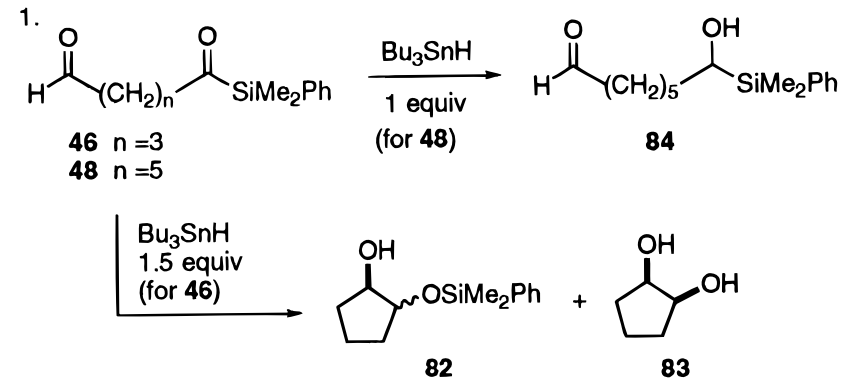

2.

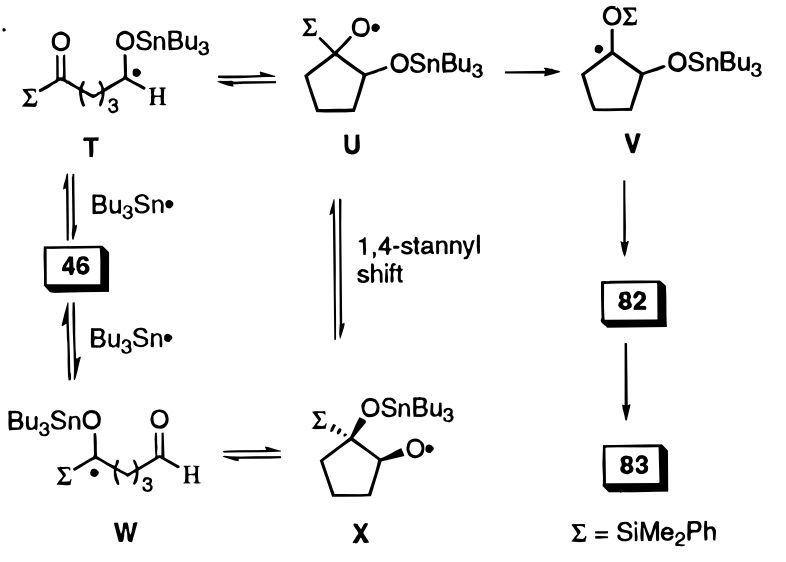

$38 \%$ yield along with unreacted starting material. It is noted that no cyclization of this type was observed in the related system of $\mathbf{3 7}$ when $\mathrm{Sml}_{2}$ was used.

Mechanistically, there are two possible pathways to account for the formation of $\mathbf{8 2}$. Stannyl radical addition to the formyl group would give O-stannyl ketyl $\mathbf{S}$ which could cyclize onto the acyl silane group to give the $\beta$-silyl alkoxy radical $\mathbf{T}$. Radical Brook rearrangement of $\mathbf{T}$ led to the formation of $\mathbf{U} .{ }^{17}$ Alternatively, the stannyl radical could also add to the acyl silane group to give the ketyl V. Addition of this radical to the formyl group would give alkoxy radical $\mathbf{W}$. In principle, a 1,4-stannyl shift might occur to give T. ${ }^{22 g, 40}$ Currently, we have no evidence to determine which pathway is preferred; however, the preferential reduction of the acyl silane moiety in $\mathbf{4 8}$ is worth noting. The stereochemical outcome was determined at the stage of hydrogen abstraction of radical $\mathbf{U}$. The moderate cis-sel ectivity, (cis-82 + 83)/trans-82 = 3:1, was likely due to the approaching of tributyltin hydride opposite to the stannyl oxy group. ${ }^{41}$ The decreased cisselectivity (1.5:1) in the formation of $\mathbf{6 7}$ (Scheme 6) was possibly due to the presence of a bulkier (tributylstannyl)methyl group which might destabilize cis-67. Compared with the case of $\mathbf{2 9}$ (Scheme 8), we attributed the lack of radical cyclization reactivity of $\mathbf{2 9}$ to the steric effect between the two bulky silyl groups. Removal of one of the silyl groups facilitated the cyclization.

\section{Conclusion}

Acyl silanes were generally reduced with $\mathrm{Sml}_{2}$ in $\mathrm{THF}$ to give the corresponding $\alpha$-silyl alcohols without transfer of silyl groups (via Brook rearrangements). Bromophenyl or succinimide substituents were inert to $\mathrm{Sml}_{2}$ under the reaction conditions. The presumed organosamarium species such as that depicted in B (Scheme 5) were

(40) (a) Davies, A. G.; Tse, M.-W. J . Organomet. Chem. 1978, 155, 25. (b) Hasegawa, E.; I shiyama, K.; Kato, T.; Horaguchi, T.; Shimizu, T. J . Org. Chem. 1992, 57, 5352.

(41) Giese, B. Angew. Chem., Int. Ed. Engl. 1989, 28, 969. successfully alkylated intra- or intermolecularly to give $\alpha$-silyl cycloalkanols or tertiary $\alpha$-silyl alcohols. The reaction of benzoyl trimethylsilane with $\mathrm{Sml}_{2}$ in the presence of HMPA also afforded a side product, benzyl phenyl ketone, presumably derived from the picanol coupling reaction followed by sequential transfers of the silyl groups.

Intramolecular radical cyclizations of 5-hexenoyl silanes were effected with $\mathrm{Sml}_{2}$ or $\mathrm{Bu}_{3} \mathrm{SnH}$ to give $\alpha$-silyl cyclopentanols. The radical cyclizations proceeded with similar mechanisms via the chairlike transition states, though $\mathrm{Sml}_{2}$ appeared to be a better reagent than $\mathrm{Bu}_{3}-$ $\mathrm{SnH}$ in these reactions. The radical cyclizations favored to give the products having the cis-configuration, though the stereoselectivity depended on the reagents and the bulkiness of silyl groups. Treatment of 1-silyl-1,5-pentanedione with $\mathrm{Bu}_{3} \mathrm{SnH}$ (Scheme 10) also yielded intramolecular cycliaztion products. Treatments of bis-acyl silanes with $\mathrm{Sml}_{2}$ or $\mathrm{Bu}_{3} \mathrm{SnH}$ generally gave reduction products (one- or two-site reduction). No radical cyclization product was formed presumably due to the steric effect between the two bulky silyl groups.

The pinacol coupling reaction of 1-(trimethylsilyl)-1,6hexanedione was carried out with $\mathrm{Sml}_{2}$ in the presence of t-BuOH (Scheme 9). On the other hand, a Tishchenko reaction occurred to give methyl 6-hydroxy-6-(trimethylsilyl)hexanoate when the reaction was conducted in the presence of $\mathrm{MeOH}$. The reaction of 1-silyl-1,5-pentanedione with $\mathrm{Sml}_{2}$ in the presence of $\mathrm{MeOH}$ proceeded similarly to give a $\delta$-silyl- $\delta$-lactone.

Unprecedent intramolecular aldol reactions of 1-(trimethylsilyl)-1,5-hexanedione was observed on treating with $\mathrm{Sml}_{2}$ (eq 1). Under the similar reaction conditions, an aldol reaction of 1,5-bis(trimethylsilyl)-1,6-hexanedione (Scheme 8) occurred by forming an (E)-enolate from one of the acyl silane group and added intramolecularly to the other acyl silane via a chelate transition state.

In summary, we have prepared a series of acyl silanes including aliphatic-, aromatic-, and bis-acyl silanes, as well as the acyl silanes bearing other substituents such as bromine atom, alkenyl, succinimide and carbonyl groups. The reactions of acyl silanes with $\mathrm{Sml}_{2}$ or $\mathrm{Bu}_{3-}$ $\mathrm{SnH}$ occurring in various manners such as reductions, reductive alkylations, intramolecular radical cyclizations, pinacol couplings, aldol reactions, and Tishchenko reactions were of synthetic interest.

\section{Experimental Section}

Melting points are uncorrected. ${ }^{1} \mathrm{H}$ NMR spectra were recorded at 200,300 , or $400 \mathrm{MHz} ;{ }^{13} \mathrm{C} N M R$ spectra were recorded at 50,75, or $100 \mathrm{MHz}$. Tetramethylsilane $(\delta=0$ ppm) was used as internal standard in ${ }^{1} \mathrm{H}$ NMR spectra. Mass spectra were recorded at an ionizing voltage of $70 \mathrm{eV}$ or 20 eV. Merck silica gel 60F sheets were used for analytical thinlayer chromatography. Column chromatography was performed on $\mathrm{SiO}_{2}$ (70-230 mesh); gradients of EtOAC and n-hexane were used as eluents. High-pressure liquid chromatography was carried out on a liquid chromatograph equipped with a refractive index detector. The samples were analyzed and/or separated on a Hibar Lichrosorb Si 60 (7 $\mu \mathrm{m})$ column $(25 \mathrm{~cm} \times 1 \mathrm{~cm})$ with the indicated eluent with a $5 \mathrm{~mL} /$ min flow rate. Benzene and THF were distilled from sodium benzophenone ketyl under $\mathrm{N}_{2}$.

General Procedure for the Preparation of 2-(Trialkylsilyl)-1,3-dithianes. To a cold $\left(0^{\circ} \mathrm{C}\right)$ stirred solution of $1,3-$ dithiane $(2 \mathrm{~g}, 16.7 \mathrm{mmol})$ in THF $(16 \mathrm{~mL})$ was added dropwise BuLi (15.1 mL of $1.6 \mathrm{M}$ solution in hexane, $22.5 \mathrm{mmol}$ ). The mixture was stirred for $10 \mathrm{~min}$, and then trialkylsilyl chloride (16.7 $\mathrm{mmol}$ ) was added in one portion. The resulting solution 
was stirred for another $30 \mathrm{~min}$ and then slowly warmed to room temperature $\left(32{ }^{\circ} \mathrm{C}\right)$. The reaction was quenched by addition of aqueous $\mathrm{NH}_{4} \mathrm{Cl}$. The mixture was concentrated, and the residue was taken up in EtOAc $(50 \mathrm{~mL})$. The organic phase was washed with brine $(2 \times 25 \mathrm{~mL})$, dried $\left(\mathrm{Na}_{2} \mathrm{SO}_{4}\right)$, and concentrated on rotary evaporation to give a crude product of 2-(trialkylsilyl)-1,3-dithiane. Separation of the product was accomplished by silica gel chromatography using EtOAcl hexane as eluent.

General Procedure for the Preparation of 2-Alkyl-2(trialkylsilyl)-1,3-dithianes. To a cold $\left(0^{\circ} \mathrm{C}\right)$ stirred solution of 2-(trialkylsilyl)-1,3-dithiane (5-10 mmol, 1 equiv) in THF (30 mL) was added dropwise BuLi (1.2 equiv of $1.6 \mathrm{M}$ solution in hexane). The mixture was stirred for $10 \mathrm{~min}$, and an alkylating agent (1.2 equiv) was added in one portion. The resulting solution was stirred for another $30 \mathrm{~min}$ and then slowly warmed to room temperature $\left(32^{\circ} \mathrm{C}\right)$. The reaction was quenched by addition of aqueous $\mathrm{NH}_{4} \mathrm{Cl}$. The mixture was concentrated, and the residue was taken up in EtOAc $(30 \mathrm{~mL})$. The organic phase was washed with brine $(2 \times 15 \mathrm{~mL})$, dried $\left(\mathrm{Na}_{2} \mathrm{SO}_{4}\right)$, and concentrated on rotary evaporation to give a crude product of 2-alkyl-2-(trialkylsilyl)-1,3-dithiane. Separation of the product was accomplished by silica gel chromatography using EtOAc/hexane as eluent.

General Procedure for the Preparation of Acyl Silanes. Method A. To a mixture of $\mathrm{BF}_{3} \cdot \mathrm{OEt}_{2}(0.73 \mathrm{~mL}, 6$ $\mathrm{mmol})$, Celite $(1 \mathrm{~g})$, and $\mathrm{HgO}(1.3 \mathrm{~g}, 6 \mathrm{mmol})$ in $10 \mathrm{~mL}$ of THF/ $\mathrm{H}_{2} \mathrm{O}(\mathrm{v} / \mathrm{v}=85: 15)$ was added 2-alkyl-2-(trialkylsilyl)-1,3dithiane in THF $(6 \mathrm{~mL})$ dropwise at room temperature $\left(28^{\circ} \mathrm{C}\right)$. The mixture was stirred for $1 \mathrm{~h}$ at room temperature $\left(28^{\circ} \mathrm{C}\right)$, after which the mixture was filtered through a short column containing silica gel and Celite. The solution was diluted with ether $(30 \mathrm{~mL})$, washed with brine $(2 \times 15 \mathrm{~mL})$, dried $\left(\mathrm{Na}_{2}\right.$ $\mathrm{SO}_{4}$ ), and concentrated on rotary evaporation to give a crude product of acyl silane. Separation of the product was accomplished by silica gel chromatography using E tOAc/hexane as eluent.

Method B. To a cold $\left(-30{ }^{\circ} \mathrm{C}\right)$ solution of 2-alkyl-2(trialkylsilyl)-1,3-dithiane (10 mmol, 1 equiv), Celite $(60 \mathrm{mg} /$ $\mathrm{mmol}$ ), and $\mathrm{NaHCO}_{3}$ (1.5 equiv) in $\mathrm{CH}_{2} \mathrm{Cl}_{2} / \mathrm{CH}_{3} \mathrm{CN}(\mathrm{v} / \mathrm{v}=3: 2$, $50 \mathrm{~mL}$ ) was added ammonium cerium(IV) nitrate (CAN, 3 equiv) in $\mathrm{CH}_{3} \mathrm{CN} / \mathrm{H}_{2} \mathrm{O}(\mathrm{v} / \mathrm{v}=15: 1,20 \mathrm{~mL})$ over a period of 10 $\mathrm{min}$. The resulting solution was stirred at $-30^{\circ} \mathrm{C}$ for $5 \mathrm{~min}$ and then diluted with $100 \mathrm{~mL}$ of ether, filtered, and partitioned with $50 \mathrm{~mL}$ of water. The ethereal phase was washed with brine $(2 \times 20 \mathrm{~mL})$, dried over $\mathrm{Na}_{2} \mathrm{SO}_{4}$, and filtered, and the filtrate was concentrated on rotary evaporation to give a crude product of acyl silane. Separation of the product was accomplished by silica gel chromatography using E tOAc/hexane as eluent.

Benzoyltrimethylsilane (2). ${ }^{23 \mathrm{~b}}$ 2-Phenyl-2-(trimethylsi|yl)-1,3-dithiane (1) was hydrolyzed with $\mathrm{HgO}$ and $\mathrm{HgCl}_{2}$ in aqueous $\mathrm{MeOH}$ to give the acyl silane 2 (82\%) according to literature. ${ }^{23}$

1-(Trimethylsilyl)hexanone (4). ${ }^{24}$ Compound 4 was prepared from hydroboration-oxidation of 1-hexynyltrimethylsilane 3 (77\%) according to literature. ${ }^{24}$

N-[3-Oxo-3-(trimethylsilyl)propyl]pyrrolidine-2,5-dione (14). Alkylation of 2-(trimethylsilyl)-1,3-dithiane (5.04 $\mathrm{mmol}$ ) with 2-chloroethanol tetrahydropyran ether $(2.16 \mathrm{~g}, 6.05$ $\mathrm{mmol}$ ), followed by hydrolysis (cat. $\mathrm{TsOH}, \mathrm{MeOH}, 25^{\circ} \mathrm{C}, 2 \mathrm{~h}$ ), gave 2-(2-hydroxyethyl)-2-(trimethylsilyl)-1,3-dithiane ${ }^{30}(0.83$ $\mathrm{g}, 70 \%)$. Solid, $\mathrm{mp} 46-48{ }^{\circ} \mathrm{C}$. Condensation of the alcohol $(0.80 \mathrm{~g}, 3.4 \mathrm{mmol})$ with succinimide $(0.4 \mathrm{~g}, 4 \mathrm{mmol})$ according to Mitsunobu procedure, using $\mathrm{PPh}_{3}(1.6 \mathrm{~g}, 5.1 \mathrm{mmol})$ and diethyl azodicarboxylate $(0.53 \mathrm{~mL}, 3.4 \mathrm{mmol})$ in $\mathrm{THF}$ at $0{ }^{\circ} \mathrm{C}$ for $12 \mathrm{~h}$, gave 2-[(2-succinimidyl)ethyl]-2-(trimethylsilyl)-1,3dithiane $(6,0.84 \mathrm{~g}, 77 \%)$. Solid, $\mathrm{mp} 134-136^{\circ} \mathrm{C}$. The dithiane $6(0.7 \mathrm{~g}, 2.57 \mathrm{mmol})$ was treated with CAN to give the title compound 14 (450 mg, 82\%). Solid, mp 125-126 ${ }^{\circ} \mathrm{C}$; TLC (EtOAc/hexane (50:50)) $\mathrm{R}_{\mathrm{f}}=0.1$; IR (KBr) 2960, 1708, 1630, 1436, 1397, 1250, $1152 \mathrm{~cm}^{-1}$; ${ }^{1} \mathrm{H}$ NMR $\left(\mathrm{CDCl}_{3}\right) \delta 0.16(\mathrm{~s}, 9 \mathrm{H})$, $2.66(\mathrm{~s}, 4 \mathrm{H}), 2.87(\mathrm{t}, \mathrm{J}=7.0 \mathrm{~Hz}, 2 \mathrm{H}), 3.70(\mathrm{t}, \mathrm{J}=7.2 \mathrm{~Hz}, 2$ $\mathrm{H}) ;{ }^{13} \mathrm{C} \mathrm{NMR}\left(\mathrm{CDCl}_{3}\right) \delta-3.4(\mathrm{q}, 3 \mathrm{C}), 28.0(\mathrm{t}, 2 \mathrm{C}), 32.9(\mathrm{t})$, $44.9(\mathrm{t}), 176.9$ (s, 2 C), 245.0 (s); MS m/ z (rel intensity) 227 $\left(\mathrm{M}^{+}, 1\right), 212$ (3), 199 (15), 170 (13), 156 (14), 103 (5), 73 (100); HRMS calcd for $\mathrm{C}_{10} \mathrm{H}_{17} \mathrm{NO}_{3} \mathrm{Si} 227.0978$, found 227.0974 .
3-(2-Bromophenyl)-1-(trimethylsilyl)propanone (15). A crude 2-[2-(o-bromophenyl)ethyl]-2-(trimethylsilyl)-1,3-dithiane $(7,0.92 \mathrm{~g}, 2.4 \mathrm{mmol}$ ), prepared from 1-bromo-2-(2-bromoethyl)benzene (0.69 g, $2.61 \mathrm{mmol}$ ) and 2-(trimethylsilyl)-1,3-dithiane $(0.5 \mathrm{~g}, 2.65 \mathrm{mmol})$, was treated with $\mathrm{HgO}(1.06 \mathrm{~g}, 4.8 \mathrm{mmol})$ and $\mathrm{BF}_{3} \cdot \mathrm{OEt}_{2}(0.59 \mathrm{~mL}, 4.8 \mathrm{mmol})$ to give the title compound 15 (302 mg, 44\%). An oil; TLC (EtOAc/hexane (2:98)) $\mathrm{R}_{\mathrm{f}}=$ 0.17; IR (neat) 3061, 2956, 2897, 1635, 1463, 1246, $1040 \mathrm{~cm}^{-1}$; ${ }^{1} \mathrm{H}$ NMR $\left(\mathrm{CDCl}_{3}\right) \delta 0.15(\mathrm{~s}, 9 \mathrm{H}), 2.90(\mathrm{~s}, 4 \mathrm{H}), 6.93-7.02(\mathrm{~m}$, $1 \mathrm{H}), 7.10-7.18(\mathrm{~m}, 2 \mathrm{H}), 7.45(\mathrm{~d}, \mathrm{~J}=7.8 \mathrm{~Hz}, 1 \mathrm{H}) ;{ }^{13} \mathrm{C} \mathrm{NMR}$ $\left(\mathrm{CDCl}_{3}\right) \delta-3.4(\mathrm{q}, 3 \mathrm{C}), 28.7(\mathrm{t}), 47.7(\mathrm{t}), 120.4(\mathrm{~s}), 127.3(\mathrm{~d})$, 127.5 (d), 130.4 (d), 132.6 (d), 140.7 (s), 246.0 (s); MS m/ z (rel intensity) $286\left(\mathrm{M}^{+}, 10\right), 271$ (17), 269 (16), 243 (13), 241 (12), 205 (29), 73 (100); HRMS calcd for $\mathrm{C}_{12} \mathrm{H}_{17} \mathrm{BrOSi} 286.0211$, found 286.0227 .

3-(2-B romophenyl)-1-(diphenylmethylsilyl)propanone (16). A crude 2-[2-(o-bromophenyl)ethyl]-2-(diphenylmethylsilyl)-1,3-dithiane $(8,2.2 \mathrm{~g}, 4.4 \mathrm{mmol})$, prepared from 1-bromo-2-(2-bromoethyl)benzene (1.32 g, $5 \mathrm{mmol}$ ) and 2-(diphenylmethylsilyl)-1,3-dithiane ( $1.58 \mathrm{~g}, 5 \mathrm{mmol})$, was treated with $\mathrm{HgO}(1.9 \mathrm{~g}, 8.8 \mathrm{mmol})$ and $\mathrm{BF}_{3} \cdot \mathrm{OEt}_{2}(1.08 \mathrm{~mL}, 8.8 \mathrm{mmol})$ to give the title compound $\mathbf{1 6}(470 \mathrm{mg}, \mathbf{2 3} \%)$. An oil; TLC (EtOAd hexane (2:98)) $\mathrm{R}_{\mathrm{f}}=0.1$; IR (neat) 3066, 3018, 2958, 1635, 1462, $1251,996 \mathrm{~cm}^{-1} ;{ }^{1} \mathrm{H} \mathrm{NMR}\left(\mathrm{CDCl}_{3}\right) \delta 0.74(\mathrm{~s}, 3 \mathrm{H}), 2.95(\mathrm{~m}, 4$ $\mathrm{H}), 6.99-7.14(\mathrm{~m}, 3 \mathrm{H}), 7.33-7.46(\mathrm{~m}, 7 \mathrm{H}), 7.55(\mathrm{~d}, \mathrm{~J}=7.8$ $\mathrm{Hz}, 4 \mathrm{H}) ;{ }^{13} \mathrm{C} \mathrm{NMR}\left(\mathrm{CDCl}_{3}\right) \delta-5.5(\mathrm{q}), 28.8(\mathrm{t}), 48.9(\mathrm{t}), 124.1$ (s), 127.3 (d), 127.5 (d), 128.1 (d, 4 C), 130.0 (d, 2 C), 130.4 (d), 132.3 (s, 2 C), 132.6 (d), 138.4 (d, 4 C), 140.4 (s), 242.6 (s); MS $\mathrm{m} / \mathrm{z}$ (rel intensity) $409\left(\mathrm{M}^{+}, 40\right), 367$ (60), 358 (25), 252 (8), 225 (36), 197 (100), 137 (10); HRMS calcd for $\mathrm{C}_{22} \mathrm{H}_{21} \mathrm{BrOSi}$ 410.0524, found 410.0537 .

5-Bromo-1-(dimethylphenylsilyl)pentanone (17). A crude 2-(4-bromobutyl)-2-(dimethyl phenylsilyl)-1,3-dithiane (9, $1.60 \mathrm{~g})$, prepared from 2-(dimethylphenylsilyl)-1,3-dithiane $(0.76 \mathrm{~g}, 3 \mathrm{mmol})$ and 1,4-dibromobutane $(1.2 \mathrm{~mL}, 9 \mathrm{mmol})$, was treated with $\mathrm{HgO}(1.3 \mathrm{~g}, 6 \mathrm{mmol})$ and $\mathrm{BF}_{3} \cdot \mathrm{OEt}_{2}(0.73 \mathrm{~mL}, 6$ $\mathrm{mmol})$ to give the title compound $\mathbf{1 7}(0.6 \mathrm{~g}, 67 \%)$. An oil; TLC (EtOAc/hexane (2:98)) $\mathrm{R}_{\mathrm{f}}=0.14$; IR (neat) 2944, 1642, 1428, 1250, 1110, 836, $818 \mathrm{~cm}^{-1}$; ${ }^{1} \mathrm{H}$ NMR $\left(\mathrm{CDCl}_{3}\right) \delta 0.47(\mathrm{~s}, 6 \mathrm{H})$, $1.53-1.74(\mathrm{~m}, 4 \mathrm{H}), 2.57(\mathrm{t}, \mathrm{J}=6.0 \mathrm{~Hz}, 2 \mathrm{H}), 3.27(\mathrm{t}, \mathrm{J}=6.0$ $\mathrm{Hz}, 2 \mathrm{H}), 7.35-7.55(\mathrm{~m}, 5 \mathrm{H}) ;{ }^{13} \mathrm{C} \mathrm{NMR}\left(\mathrm{CDCl}_{3}\right) \delta-4.8(\mathrm{q}, 2$ C), $20.7(\mathrm{t}), 32.0(\mathrm{t}), 33.2(\mathrm{t}), 47.4(\mathrm{t}), 128.1(\mathrm{~d}, 2 \mathrm{C}), 129.9(\mathrm{~d})$, 138.8 (d, 2 C), 154.2 (s), 245.4 (s); MS m/ z (rel intensity) 299 (M+ - 1, 0.5), 297 (0.5), 271 (2), 269 (2), 201 (8), 199 (8), 135 (100); HRMS calcd for $\mathrm{C}_{13} \mathrm{H}_{19}$ BrOSi 300.0369, found 300.0367 .

6-Bromo-1-(tert-butyldimethylsilyl)hexanone (18). A crude 2-(5-bromopentyl)-2-(tert-butyldimethylsilyl)-1,3-dithiane (10, $1.04 \mathrm{~g})$, prepared from 2-(tert-butyldimethylsilyl)-1,3dithiane $(0.7 \mathrm{~g}, 3 \mathrm{mmol})$ and 1,5-dibromopenane $(1.2 \mathrm{~mL}, 9$ $\mathrm{mmol})$, was treated with $\mathrm{HgO}(1.39 \mathrm{~g}, 6 \mathrm{mmol})$ and $\mathrm{BF}_{3} \cdot \mathrm{OEt}_{2}$ $(0.73 \mathrm{~mL}, 6 \mathrm{mmol})$ to give the title compound $\mathbf{1 8}(0.61 \mathrm{~g}, 70 \%)$. An oil; TLC (EtOAc/hexane (5:95)) $R_{f}=0.3$; IR (neat) 2927, 2854, 1634, 1459, 1248, 837, $775 \mathrm{~cm}^{-1} ;{ }^{1} \mathrm{H} \mathrm{NMR}\left(\mathrm{CDCl}_{3}\right) \delta 0.15$ $(\mathrm{s}, 6 \mathrm{H}), 0.90(\mathrm{~s}, 9 \mathrm{H}), 1.31-1.59(\mathrm{~m}, 4 \mathrm{H}), 1.82$ (quin, J $=7.2$ $\mathrm{Hz}, 2 \mathrm{H}), 2.58(\mathrm{t}, \mathrm{J}=7.0 \mathrm{~Hz}, 2 \mathrm{H}), 3.37(\mathrm{t}, \mathrm{J}=6.8 \mathrm{~Hz}, 2 \mathrm{H})$; ${ }^{13} \mathrm{C}$ NMR $\left(\mathrm{CDCl}_{3}\right) \delta-7.0(\mathrm{q}, 2 \mathrm{C}), 16.4(\mathrm{~s}), 20.9(\mathrm{t}), 26.3(\mathrm{q}, 3$

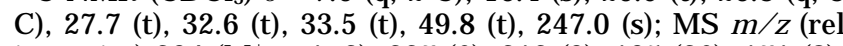
intensity) $294\left(\mathrm{M}^{+}+1,2\right), 237$ (6), 213 (9), 195 (26), 171 (8), 115 (82), 73 (100); HRMS calcd for $\mathrm{C}_{12} \mathrm{H}_{25} \mathrm{BrOSi} 292.0858$, found 292.0855 .

7-Bromo-1-(trimethylsilyl)heptanone (19). A crude 2-(6bromohexyl)-2-(trimethylsilyl)-1,3-dithiane (11, $0.97 \mathrm{~g})$, prepared from 2-(trimethylsilyl)-1,3-dithiane $(0.58 \mathrm{~g}, 3 \mathrm{mmol})$ and 1,6-dibromohexane $(1.38 \mathrm{~mL}, 9 \mathrm{mmol})$, was treated with $\mathrm{HgO}$ $(1.39 \mathrm{~g}, 6 \mathrm{mmol})$ and $\mathrm{BF}_{3} \cdot \mathrm{OEt}_{2}(0.73 \mathrm{~mL}, 6 \mathrm{mmol})$ to give the title compound $19(0.52 \mathrm{~g}, 65 \%)$. An oil; TLC (EtOAc/hexane $(10: 90)) R_{f}=0.5$; IR (neat) 2934, 2858, 1634, 1457, 1246, 844, $750 \mathrm{~cm}^{-1} ;{ }^{1} \mathrm{H}$ NMR $\left(\mathrm{CDCl}_{3}\right) \delta 0.13(\mathrm{~s}, 9 \mathrm{H}), 1.16-1.54(\mathrm{~m}, 6$ $\mathrm{H}$ ), 1.78 (quin, $\mathrm{J}=6.8 \mathrm{~Hz}, 2 \mathrm{H}$ ), $2.54(\mathrm{t}, \mathrm{J}=7.0 \mathrm{~Hz}, 2 \mathrm{H}$ ), 3.33 $(\mathrm{t}, \mathrm{J}=6.8 \mathrm{~Hz}, 2 \mathrm{H}) ;{ }^{13} \mathrm{C} \mathrm{NMR}\left(\mathrm{CDCl}_{3}\right) \delta-3.2(\mathrm{q}, 3 \mathrm{C}), 21.7(\mathrm{t})$, $27.8(\mathrm{t}), 28.3(\mathrm{~d}), 32.4(\mathrm{t}), 33.6(\mathrm{t}), 48.0(\mathrm{t}), 248.0(\mathrm{~s}) ; \mathrm{MS} \mathrm{m} / \mathrm{z}$ (rel intensity) $251\left(\mathrm{M}^{+}-15,1\right), 249$ (1), 185 (2), 139 (6), 101 (6), 95 (15), 73 (100); HRMS calcd for $\mathrm{C}_{10} \mathrm{H}_{21}$ BrOSi 266.0524, found 266.0527 .

1-(Trimethylsilyl)-5-hexenone (20). 2-(4-Pentyl)-2-(trimethylsilyl)-1,3-dithiane $(\mathbf{1 2}, 1.83 \mathrm{~g}, 7 \mathrm{mmol})$, prepared from 2-(trimethylsilyl)-1,3-dithiane (1.92 g, $10 \mathrm{mmol}$ ) and 5-bromo- 
1-pentene (1.42 mL, $12 \mathrm{mmol}$ ), was treated with CAN (11.5 g, $21 \mathrm{mmol}$ ) to give the title compound $20(0.91 \mathrm{~g}, 76 \%)$. An oil; TLC (EtOAc/hexane (2:98)) $\mathrm{R}_{\mathrm{f}}=0.3$; IR (neat) 2954, 1634, 1436, 1399, 1247, 911, $845 \mathrm{~cm}^{-1}$; ${ }^{1} \mathrm{H}$ NMR $\left(\mathrm{CDCl}_{3}\right) \delta 0.12$ (s, 9 $\mathrm{H}), 1.55$ (quin, J = $7.2 \mathrm{~Hz}, 2 \mathrm{H}$ ), $1.95(\mathrm{q}, \mathrm{J}=7.2 \mathrm{~Hz}, 2 \mathrm{H}$ ), 2.53 $(\mathrm{t}, \mathrm{J}=7.2 \mathrm{~Hz}, 2 \mathrm{H}), 4.86-4.96(\mathrm{~m}, 2 \mathrm{H}), 5.57-5.78(\mathrm{~m}, 1 \mathrm{H})$; ${ }^{13} \mathrm{C} N M R\left(\mathrm{CDCl}_{3}\right) \delta-3.3(\mathrm{q}, 3 \mathrm{C}), 21.1(\mathrm{t}), 33.1(\mathrm{t}), 47.4(\mathrm{t})$, 114.9 (t), 138.1 (d), 247.0 (s); MS m/ z (rel intensity) $170\left(\mathrm{M}^{+}\right.$, 3), 169 (4), 155 (5), 127 (6), 101 (5), 75 (20), 73 (100); HRMS calcd for $\mathrm{C}_{9} \mathrm{H}_{18} \mathrm{OSi} 170.1127$, found 170.1126 .

1-(Diphenylmethylsilyl)-5-hexenone (21). 2-(4-Pentyl)2-(diphenylmethylsilyl)-1,3-dithiane (13, $2.8 \mathrm{~g}, 7.3 \mathrm{mmol})$, prepared from 2-(diphenylmethylsilyl)-1,3-dithiane (2.4 g, 7.5 $\mathrm{mmol}$ ) and 5-bromo-1-pentene (1.07 mL, $9.12 \mathrm{mmol}$ ), was treated with CAN $(11.9 \mathrm{~g}, 21.9 \mathrm{mmol})$ to give the title compound 21 (1.62 g, 76\%). An oil; TLC (EtOAc/hexane (2: 98)) $R_{f}=0.2$; IR (neat) 3064, 3044, 2929, 1636, 1424, 1111, $997 \mathrm{~cm}^{-1} ;{ }^{1} \mathrm{H}$ NMR $\left(\mathrm{CDCl}_{3}\right) \delta 0.73(\mathrm{~s}, 3 \mathrm{H}), 1.56$ (quin, J $=7.4$ $\mathrm{Hz}, 2 \mathrm{H}), 1.92(\mathrm{q}, \mathrm{J}=7.4 \mathrm{~Hz}, 2 \mathrm{H}), 2.65(\mathrm{t}, \mathrm{J}=7.4 \mathrm{~Hz}, 2 \mathrm{H})$, 4.83-4.93 (m, $2 \mathrm{H}), 5.55-5.75(\mathrm{~m}, 1 \mathrm{H}), 7.33-7.43(\mathrm{~m}, 6 \mathrm{H})$, 7.51-7.59 (m, $4 \mathrm{H}) ;{ }^{13} \mathrm{C} \mathrm{NMR}\left(\mathrm{CDCl}_{3}\right) \delta-5.3,21.2,33.0,48.8$ $115.0,128.2,130.1,132.8,135.0,138.1,244.3 ; \mathrm{MS} \mathrm{m} / \mathrm{z}$ (rel intensity) 294 (M+, 8), 293 (41), 197 (100), 137 (20), 84 (20), 49 (51); HRMS calcd for $\mathrm{C}_{19} \mathrm{H}_{22} \mathrm{OSi} 294.1442$, found 294.1441 .

1,5-Bis(trimethylsilyl)-1,5-pentanedione (28). To a cold $\left(0^{\circ} \mathrm{C}\right)$ stirred solution of 2-(trimethylsilyl)-1,3-dithiane (962 $\mathrm{mg}, 5 \mathrm{mmol})$ in THF (5 mL) was added dropwise BuLi (3.43 $\mathrm{mL}$ of $1.6 \mathrm{M}$ solution in hexane, $5.5 \mathrm{mmol}$ ) under $\mathrm{Ar}$. The mixture was stirred at $0{ }^{\circ} \mathrm{C}$ for $20 \mathrm{~min}$, and then 1,3dibromopropane $(0.25 \mathrm{~mL}, 2.5 \mathrm{mmol})$ was added. The resulting solution was stirred for another $30 \mathrm{~min}$, and quenched by addition of aqueous $\mathrm{NH}_{4} \mathrm{Cl}$. The volatile components were removed by rotary evaporator, and the residue was taken up in EtOAc. The organic phase was washed with brine $(2 \times 15$ $\mathrm{mL})$, dried $\left(\mathrm{Na}_{2} \mathrm{SO}_{4}\right)$, and concentrated on rotary evaporation to give a crude product of bis-dithiane 24 (1.26 g). To a mixture of $\mathrm{BF}_{3} \cdot \mathrm{OEt}_{2}(1.48 \mathrm{~mL}, 12 \mathrm{mmol})$, Celite $(1 \mathrm{~g})$, and $\mathrm{HgO}$ $(2.5 \mathrm{~g}, 12 \mathrm{mmol})$ in $10 \mathrm{~mL}$ of $\mathrm{THF} / \mathrm{H}_{2} \mathrm{O}(\mathrm{v} / \mathrm{v}=85: 15)$ was added the crude bis-dithiane $\mathbf{2 4}$ in THF (3 mL) dropwise at room temperature. The mixture was stirred for $20 \mathrm{~min}$ and filtered through a short column containing silica gel and Celite. The solution was partitioned between ether $(20 \mathrm{~mL})$ and water (10 $\mathrm{mL})$, washed with brine $(2 \times 15 \mathrm{~mL})$, dried $\left(\mathrm{Na}_{2} \mathrm{SO}_{4}\right)$, and concentrated on rotary evaporation. The residue was purified by silica gel chromatography with elution of EtOAc/hexane ( 5 : 95) to give the title compound $\mathbf{2 8}$ (412 $\mathrm{mg}, 68 \%)$. An oil; TLC (EtOAc/hexane (5:95)) $\mathrm{R}_{\mathrm{f}}=0.23$; IR (neat) 2958, 2901, 1642, $1401,1249,844,753 \mathrm{~cm}^{-1}$; ${ }^{1} \mathrm{H}$ NMR $\left(\mathrm{CDCl}_{3}\right) \delta 0.15(\mathrm{~s}, 18 \mathrm{H})$ 1.70 (quin, $\mathrm{J}=6.8 \mathrm{~Hz}, 2 \mathrm{H}), 2.56(\mathrm{t}, \mathrm{J}=6.8 \mathrm{~Hz}, 4 \mathrm{H}) ;{ }^{13} \mathrm{C}$ NMR $\left(\mathrm{CDCl}_{3}\right) \delta-3.3(\mathrm{q}, 6 \mathrm{C}), 14.7(\mathrm{t}), 47.3(\mathrm{t}, 2 \mathrm{C}), 247.7(\mathrm{~s}, 2$ C); MS m/ z (rel intensity) 244 ( $\left.\mathrm{M}^{+}, 20\right), 188$ (1),173 (5), 147 (55), 133 (8), 115 (3), 73 (100); HRMS calcd for $\mathrm{C}_{11} \mathrm{H}_{24} \mathrm{O}_{2} \mathrm{Si}_{2}$ 244.1315 , found 244.1311 .

1,5-Bis(diphenylmethylsilyl)-1,5-pentanedione (29). Bisdithiane 25, prepared from dithiane $23(0.44 \mathrm{~g}, 1.4 \mathrm{mmol})$ and 1-bromo-3-chloropropane ( $69 \mu \mathrm{L}, 0.7 \mathrm{mmol})$, was treated with $\mathrm{HgO}(0.75 \mathrm{~g}, 3.5 \mathrm{mmol})$, Celite $(0.65 \mathrm{~g})$, and $\mathrm{BF}_{3} \cdot \mathrm{OEt}_{2}(0.35$ $\mathrm{mL}, 2.8 \mathrm{mmol}$ ), by a procedure similar to that for $\mathbf{2 8}$, to give 29 (172 mg, 50\%) as a light yellow liquid. IR (neat) 3065, 1638, 1425, 1395, 1252, 1112, 997, 792, 728, $696 \mathrm{~cm}^{-1}$; ${ }^{1} \mathrm{H}$ NMR $\left(\mathrm{CDCl}_{3}\right) \delta 0.70(\mathrm{~s}, 6 \mathrm{H}), 1.67$ (quintet, J $\left.=7.0 \mathrm{~Hz}, 2 \mathrm{H}\right), 2.56(\mathrm{t}$, $\mathrm{J}=7.0 \mathrm{~Hz}, 4 \mathrm{H}), 7.29-7.66(\mathrm{~m}, 20 \mathrm{H}) ;{ }^{13} \mathrm{C} \mathrm{NMR}\left(\mathrm{CDCl}_{3}\right) \delta$ $-5.4,14.8,48.6,128.2,130.1,132.6,134.9,243.8 ; \mathrm{MS} \mathrm{m} / \mathrm{z}$ (rel intensity) $492\left(\mathrm{M}^{+}, 70\right), 356$ (6), 333 (15), 255 (21), 197 (100), 117 (11); HRMS calcd for $\mathrm{C}_{31} \mathrm{H}_{32} \mathrm{O}_{2} \mathrm{Si}_{2}$ 492.1942, found 492.1942.

1,6-Bis(trimethylsilyl)-1,6-hexanedione (30). Compound 30 (65\% yield) was prepared from bis-dithiane $\mathbf{2 6}$ by a procedure similar to that for 28. An oil; TLC (EtOAc/hexane $(5: 95)) R_{f}=0.28$; IR (neat) 2956, 2901, 1641, 1402, 1249, 844, $752 \mathrm{~cm}^{-1} ;{ }^{1} \mathrm{H}$ NMR $\left(\mathrm{CDCl}_{3}\right) \delta 0.15(\mathrm{~s}, 18 \mathrm{H}), 1.43(\mathrm{~m}, 4 \mathrm{H})$, $2.55(\mathrm{t}, \mathrm{J}=6.8 \mathrm{~Hz}, 4 \mathrm{H}) ;{ }^{13} \mathrm{C} \mathrm{NMR}\left(\mathrm{CDCl}_{3}\right) \delta-3.1(\mathrm{q}, 6 \mathrm{C})$, $21.7(\mathrm{t}, 2 \mathrm{C}), 48.2(\mathrm{t}, 2 \mathrm{C}), 247.9(\mathrm{~s}, 2 \mathrm{C}) ; \mathrm{MS} \mathrm{m} / \mathrm{z}$ (rel intensity) $258\left(\mathrm{M}^{+}, 15\right), 217$ (2), 157 (15), 147 (28), 129 (3), 101 (2), 73 (100); HRMS calcd for $\mathrm{C}_{12} \mathrm{H}_{26} \mathrm{O}_{2} \mathrm{Si}_{2} 258.1471$, found 258.1479.

1,8-Bis(trimethylsilyl)-1,8-octanedione (31). Compound 31 (61\% yield) was prepared from bis-dithiane 27 by a procedure similar to that for $\mathbf{2 8}$. An oil; TLC (EtOAc/hexane
(10:90)) $R_{f}=0.5$; IR (neat) 2934, 1635, 1457, 1398, 1246, 846, $752 \mathrm{~cm}^{-1}$; ${ }^{1} \mathrm{H}$ NMR $\left(\mathrm{CDCl}_{3}\right) \delta 0.10(\mathrm{~s}, 18 \mathrm{H}), 1.16$ (quin, J = $6.8 \mathrm{~Hz}, 4 \mathrm{H}$ ), 1.41 (quin, J $=6.8 \mathrm{~Hz}, 4 \mathrm{H}$ ), $2.50(\mathrm{t}, \mathrm{J}=7.2 \mathrm{~Hz}$, $4 \mathrm{H}) ;{ }^{13} \mathrm{C} \mathrm{NMR}\left(\mathrm{CDCl}_{3}\right) \delta-3.2(\mathrm{q}, 6 \mathrm{C}), 21.8(\mathrm{t}, 2 \mathrm{C}), 29.0$ (t, 2 C), 48.2 (t, 2 C), 248.0 (s, 2 C); MS m/ z (rel intensity) 286 $\left(\mathrm{M}^{+}, 3\right), 243$ (3), 217 (6), 204 (3), 185 (9), 147 (27), 73 (100); HRMS calcd for $\mathrm{C}_{14} \mathrm{H}_{30} \mathrm{O}_{2} \mathrm{Si}_{2} 286.1784$, found 286.1797 .

1-(Trimethylsilyl)-1,5-hexanedione (33). Compound 32 (160 mg, $0.5 \mathrm{mmol}$ ), prepared from 2-(trimethylsilyl)-1,3dithiane (2 g, $10.4 \mathrm{mmol})$ and 5-chloro-2-pentanone ethylene ketal $(1.65 \mathrm{~mL}, 11 \mathrm{mmol}$, purchased from Aldrich Co.), was treated with $\mathrm{HgO}(216.5 \mathrm{mg}, 1 \mathrm{mmol})$ and $\mathrm{BF}_{3} \cdot \mathrm{OEt}_{2}(0.12 \mathrm{~mL}$, $1 \mathrm{mmol})$ in $\mathrm{THF} / \mathrm{H}_{2} \mathrm{O}(6.8 \mathrm{~mL} / 1.2 \mathrm{~mL})$ to give the title compound 33 (75 mg, 81\%) and its ethylene acetal 34 (15 mg, $13 \%)$. When the reaction was performed in $\mathrm{Me} \mathrm{CO}_{2} \mathrm{CH} \mathrm{H}_{2} \mathrm{O}(6.8$ $\mathrm{mL} / 1.2 \mathrm{~mL})$, only 33 (85 mg, 91\%) was obtained. 33: An oil; TLC (EtOAc/hexane (5:95)) $\mathrm{R}_{\mathrm{f}}=0.14$; IR (neat) 2957, 2900, $1715,1641,1366,1249,845 \mathrm{~cm}^{-1} ;{ }^{1} \mathrm{H} N M R\left(\mathrm{CDCl}_{3}\right) \delta 0.16(\mathrm{~s}$, $9 \mathrm{H}$ ), 1.76 (quin, J = $7.0 \mathrm{~Hz}, 2 \mathrm{H}$ ), $2.09(\mathrm{~s}, 3 \mathrm{H}$ ), $2.39(\mathrm{t}, \mathrm{J}=$ $7.0 \mathrm{~Hz}, 2 \mathrm{H}), 2.60(\mathrm{t}, \mathrm{J}=7.0 \mathrm{~Hz}, 2 \mathrm{H}) ;{ }^{13} \mathrm{C} \mathrm{NMR}\left(\mathrm{CDCl}_{3}\right) \delta$ $-3.2(\mathrm{q}, 3 \mathrm{C}), 16.2(\mathrm{t}), 29.8(\mathrm{q}), 42.7(\mathrm{t}), 47.1(\mathrm{t}), 208.5(\mathrm{~s}), 247.6$ (s); MS m/ z (rel intensity) $186\left(\mathrm{M}^{+}, 2\right), 168(4), 153(6), 130$ (56), 115 (80), 101 (8), 73 (100); HRMS calcd for $\mathrm{C}_{9} \mathrm{H}_{18} \mathrm{O}_{2} \mathrm{Si}$ 186.1076, found 186.1094. 34: An oil; TLC (EtOAC/hexane $(5: 95)) R_{f}=0.1$; IR (neat) 2955, 2882, 1716, 1362, 1246, 1105, $840 \mathrm{~cm}^{-1} ;{ }^{1} \mathrm{H}$ NMR $\left(\mathrm{CDCl}_{3}\right) \delta 0.05(\mathrm{~s}, 9 \mathrm{H}), 1.54-1.60(\mathrm{~m}, 4$ $\mathrm{H}), 2.10(\mathrm{~s}, 3 \mathrm{H}), 2.40(\mathrm{t}, \mathrm{J}=6.6 \mathrm{~Hz}, 2 \mathrm{H}), 3.79-3.81(\mathrm{~m}, 2 \mathrm{H})$, $3.91-3.96(\mathrm{~m}, 2 \mathrm{H}) ;{ }^{13} \mathrm{C} N M R\left(\mathrm{CDCl}_{3}\right) \delta-3.2(\mathrm{q}, 3 \mathrm{C}), 17.7(\mathrm{t})$, $29.8(\mathrm{q}), 35.9(\mathrm{t}), 43.9(\mathrm{t}), 65.2(\mathrm{t}, 2 \mathrm{C}), 109.0(\mathrm{~s}), 208.8(\mathrm{~s}) ; \mathrm{MS}$ $\mathrm{m} / \mathrm{z}$ (rel intensity) $231\left(\mathrm{M}^{+}+1,30\right), 215$ (9), 201 (10), 157 (100), 145 (31), 99 (60), 73 (65); HRMS calcd for $\mathrm{C}_{10} \mathrm{H}_{19} \mathrm{O}_{3} \mathrm{Si}$ 215.1103 , found 215.1113 .

1-(Trimethylsilyl)-1,5-pentanedione (37). A mixture of 2-(trimethylsilyl)-1,3-dithiane (2 equiv) and 4-chlorobutanol (2 equiv) in THF was treated with LDA (3.3 equiv) at $-78^{\circ} \mathrm{C}$ gave 35 in quantitative yield. To a suspension of $35(2.64 \mathrm{~g}$, $10 \mathrm{mmol}), 4 \mathrm{~A}$ molecular sieve $(5 \mathrm{~g})$, and Celite $(2.64 \mathrm{~g})$ in $\mathrm{CH}_{2^{-}}$ $\mathrm{Cl}_{2}(40 \mathrm{~mL})$ was added PCC $(4.31 \mathrm{~g}, 20 \mathrm{mmol})$ at $0{ }^{\circ} \mathrm{C}$. The mixture was warmed to room temperature and stirred for 1 h. The reaction was quenched by addition of $30 \mathrm{~mL}$ of EtOAc/ hexane (9:1) and filtered. The solvent was removed on rotary evaporation and purified by silica gel chromatography with elution of EtOAc/hexane (10:90) to give 4-[1-(trimethylsilyl)2,6-dithiacyclohexyl]butanal (36) (1.17 g, 45\%). Aldehyde 36 (262 mg, $1 \mathrm{mmol}$ ) was treated with $\mathrm{HgO}(500 \mathrm{mg}, 2.3 \mathrm{mmol}$ ) and $\mathrm{BF}_{3} \cdot \mathrm{OEt}_{2}(0.12 \mathrm{~mL}, 1 \mathrm{mmol})$ to give the title compound 37 (133 mg, 77\%) and its dihydropyran derivative 38 (26 mg, 15\%). 36: An oil; TLC (EtOAc/hexane (10:90)) $R_{f}=0.26$; I $R$ (neat) $2950,2850,1722,1248,844 \mathrm{~cm}^{-1} ;{ }^{1} \mathrm{H}$ NMR $\left(\mathrm{CDCl}_{3}\right) \delta$ $0.18(\mathrm{~s}, 9 \mathrm{H}), 1.79-2.05(\mathrm{~m}, 4 \mathrm{H}), 2.39-2.52(\mathrm{~m}, 4 \mathrm{H}), 3.00(\mathrm{br}$ $\mathrm{t}, \mathrm{J}=14.0 \mathrm{~Hz}, 2 \mathrm{H}), 9.78(\mathrm{t}, \mathrm{J}=1.2 \mathrm{~Hz}, 1 \mathrm{H}) ;{ }^{13} \mathrm{C} \mathrm{NMR}\left(\mathrm{CDCl}_{3}\right)$ $\delta-2.5(\mathrm{q}, 3 \mathrm{C}), 20.3(\mathrm{t}), 23.3(\mathrm{t}, 2 \mathrm{C}), 24.9(\mathrm{t}), 36.7(\mathrm{t}), 38.4(\mathrm{~s})$, 43.9 (t), 201.9 (s). 37: An oil; TLC (EtOAc/hexane (10:90)) $\mathrm{R}_{\mathrm{f}}$ $=0.17$; IR (neat) 2956, 1723, 1640, 1407, 1249, 845, $753 \mathrm{~cm}^{-1}$; ${ }^{1} \mathrm{H} \mathrm{NMR}\left(\mathrm{CDCl}_{3}\right) \delta 0.15(\mathrm{~s}, 9 \mathrm{H}), 1.82$ (quin, J $=7.0 \mathrm{~Hz}, 2 \mathrm{H}$ ), $2.41(\mathrm{t}, \mathrm{J}=7.0 \mathrm{~Hz}, 2 \mathrm{H}), 2.64(\mathrm{t}, \mathrm{J}=7.0 \mathrm{~Hz}, 2 \mathrm{H}), 9.70(\mathrm{t}, \mathrm{J}=$ $1.4 \mathrm{~Hz}, 1 \mathrm{H}) ;{ }^{13} \mathrm{C} \mathrm{NMR}\left(\mathrm{CDCl}_{3}\right) \delta-3.2(\mathrm{q}, 3 \mathrm{C}), 14.5(\mathrm{t}), 43.1$ (t), 46.9 (t), 202.0 (d), 247.1 (s); MS m/ z (rel intensity) 172 ( $\mathrm{M}^{+}$, 4), 157 (10), 116 (30), 101 (44), 73 (100), 59 (8), 45 (12); HRMS calcd for $\mathrm{C}_{8} \mathrm{H}_{16} \mathrm{O}_{2} \mathrm{Si} 172.0919$, found 172.0925. 38: An oil; TLC (EtOAc/hexane (10:90)) $\mathrm{R}_{\mathrm{f}}=0.22$; IR (neat) 3400, 2956, 1622, 1407, 1247, 1221, 1041, $842 \mathrm{~cm}^{-1} ;{ }^{1} \mathrm{H} \mathrm{NMR}\left(\mathrm{CDCl}_{3}\right)$ $\delta 0.06(\mathrm{~s}, 9 \mathrm{H}), 1.68-2.17(\mathrm{~m}, 4 \mathrm{H}), 2.97(\mathrm{~d}, \mathrm{~J}=4.5 \mathrm{~Hz}, 1 \mathrm{H})$, $5.04(\mathrm{t}, \mathrm{J}=3.9 \mathrm{~Hz}, 1 \mathrm{H}), 5.26(\mathrm{br} \mathrm{d}, \mathrm{J}=2.4 \mathrm{~Hz}, 1 \mathrm{H})$; ${ }^{13} \mathrm{C} \mathrm{NMR}$ $\left(\mathrm{CDCl}_{3}\right) \delta-2.5(\mathrm{q}, 3 \mathrm{C}), 17.2(\mathrm{t}), 27.3(\mathrm{t}), 91.6(\mathrm{~d}), 110.6(\mathrm{~d})$, 156.8 (s); MS m/ z (rel intensity) $172\left(\mathrm{M}^{+}, 5\right), 157$ (7), $116(20)$, 101 (35), 73 (100), 59 (7), 45 (7); HRMS calcd for $\mathrm{C}_{8} \mathrm{H}_{15} \mathrm{O}_{2} \mathrm{Si}$ 171.0841 , found 171.0856

1,3-Bis(2,6-dithiacyclohexyl)propane (39).28 To a mixture of a $50 \%$ aqueous solution of glutaric dialdehyde (2.72 $\mathrm{mL}, 15 \mathrm{mmol}), 1,3$-propanedithiol $(3.0 \mathrm{~mL}, 30 \mathrm{mmol})$, and $\mathrm{CHCl}_{3}(40 \mathrm{~mL})$ was added $\mathrm{BF}_{3} \cdot \mathrm{OEt}_{2}(1.0 \mathrm{~mL}, 11 \mathrm{mmol})$ in several portions over 2 days. The resulting mixture was partitioned between ether $(100 \mathrm{~mL})$ and water $(80 \mathrm{~mL})$. The organic phase was washed with brine $(50 \mathrm{~mL})$, dried $\left(\mathrm{MgSO}_{4}\right)$, and concentrated in vacuo. The residue was chromatographed on silica gel (EtOAc/hexane (4:96)) to give 39 ( $2.3 \mathrm{~g}, 55 \%)$ as a 
white solid; $\mathrm{mp} 100-100.5^{\circ} \mathrm{C}$ (lit. ${ }^{28} 101.5-102{ }^{\circ} \mathrm{C}$ ); IR $\left(\mathrm{CH}_{2^{-}}\right.$ $\left.\mathrm{Cl}_{2}\right)$ 2937, 2901, 1417, 1183, 1008, 906, $697 \mathrm{~cm}^{-1}$; ${ }^{1} \mathrm{H} \mathrm{NMR}$ $\left(\mathrm{CDCl}_{3}\right) \delta 1.65-2.00(\mathrm{~m}, 8 \mathrm{H}), 2.00-2.18(\mathrm{~m}, 2 \mathrm{H}), 2.73-2.97$ $(\mathrm{m}, 8 \mathrm{H}), 4.01(\mathrm{br} \mathrm{t}, \mathrm{J}=6 \mathrm{~Hz}, 2 \mathrm{H}) ;{ }^{13} \mathrm{C} \mathrm{NMR}\left(\mathrm{CDCl}_{3}\right) \delta 23.7$, 25.9, 30.3, 34.7, 47.1.

1,5-Bis(2,6-dithiacyclohexyl)pentane (41). Alkylation of 1,3-dithiane ( $2.4 \mathrm{~g}, 20 \mathrm{mmol}$ ) with 1,5-dibromopentane (1.36 $\mathrm{mL}, 10 \mathrm{mmol}$ ), by a procedure similar to that reported for $\mathbf{2 8}$, gave 41 (2.34 g, 76\%) as a white solid. Mp 56-57 ${ }^{\circ} \mathrm{C}$; IR $\left(\mathrm{CH}_{2-}\right.$ $\mathrm{Cl}_{2}$ ) 2935, 2903, 2856, 1455, 1419, 1410, 1271, 1182, 907, 732, $697 \mathrm{~cm}^{-1} ; 1 \mathrm{H}$ NMR $\left(\mathrm{CDCl}_{3}\right) \delta 1.20-1.33$ (quintet, J $=7.0 \mathrm{~Hz}$, $4 \mathrm{H}), 1.65-1.75(\mathrm{q}, \mathrm{J}=7.0 \mathrm{~Hz}, 4 \mathrm{H}), 1.75-1.90(\mathrm{~m}, 2 \mathrm{H}), 2.72-$ $2.90(\mathrm{~m}, 8 \mathrm{H}), 3.98(\mathrm{t}, \mathrm{J}=7.0 \mathrm{~Hz}, 2 \mathrm{H}) ;{ }^{13} \mathrm{C} \mathrm{NMR}\left(\mathrm{CDCl}_{3}\right) \delta$ $25.9,26.2,28.7,30.4,35.2,47.4$. Anal. Calcd for $\mathrm{C}_{13} \mathrm{H}_{24} \mathrm{~S}_{4}$ : C, 50.61; H, 7.84. Found: C, 50.64; H, 7.75.

1-(Dimethylphenylsilyl)-1,5-pentanedione (46). To a solution of $39(1.1 \mathrm{~g}, 3.9 \mathrm{mmol})$ in dry THF $(5 \mathrm{~mL})$ was added dropwise at $0{ }^{\circ} \mathrm{C}$ a hexane solution of BuLi $(1.55 \mathrm{M}, 3.0 \mathrm{~mL})$. The reaction mixture was stirred at $0{ }^{\circ} \mathrm{C}$ for $10 \mathrm{~min}$ followed by the addition of dimethylphenylchlorosilane $(0.71 \mathrm{~mL}, 4.3$ $\mathrm{mmol}$ ) in one portion. The resulting mixture was stirred at 0 ${ }^{\circ} \mathrm{C}$ for $10 \mathrm{~min}$ and then partitioned between ether $(80 \mathrm{~mL})$ and water $(50 \mathrm{~mL})$. The organic layer was washed with brine (50 $\mathrm{mL})$, dried $\left(\mathrm{MgSO}_{4}\right)$, and concentrated in vacuo to give a liquid. The liquid was mixed with red $\mathrm{HgO}(3.37 \mathrm{~g}, 15.6 \mathrm{mmol}$ ), THF $(16 \mathrm{~mL})$, and water $(2 \mathrm{~mL})$, followed by the addition of $\mathrm{BF}_{3}$. $\mathrm{OEt}_{2}(1.2 \mathrm{~mL}, 10 \mathrm{mmol})$ in one portion. The resulting mixture was stirred at room temperature for $20 \mathrm{~min}$, diluted with ether $(50 \mathrm{~mL})$, and filtered through a short pad of silica gel. The filtrate was washed with water $(30 \mathrm{~mL})$, brine $(30 \mathrm{~mL})$, dried $\left(\mathrm{MgSO}_{4}\right)$, and concentrated in vacuo to give a liquid. The liquid was chromatographed on silica gel (EtOAc/hexane $(2: 8)$ with the addition of a few drops of $\left.E_{3} \mathrm{~N}\right)$ to afford $\mathbf{4 6}(0.64 \mathrm{~g}, 70 \%)$ as a light yellow liquid. IR (neat) 2956, 1717, 1633, 1423, 1247, 1110, 836, 779, 735, $700 \mathrm{~cm}^{-1} ;{ }^{1} \mathrm{H}$ NMR $\left(\mathrm{CDCl}_{3}\right) \delta 0.47(\mathrm{~s}, 6$ $\mathrm{H}$ ), 1.76 (quintet, J $=7.0 \mathrm{~Hz}, 2 \mathrm{H}$ ), 2.31 (td, J $=7.0,1.4 \mathrm{~Hz}$, $2 \mathrm{H}), 2.60(\mathrm{t}, \mathrm{J}=7.0 \mathrm{~Hz}, 2 \mathrm{H}), 7.25-7.40(\mathrm{~m}, 3 \mathrm{H}), 7.45-7.60$ $(\mathrm{m}, 2 \mathrm{H}), 9.62(\mathrm{t}, \mathrm{J}=1.4 \mathrm{~Hz}, 1 \mathrm{H}) ;{ }^{13} \mathrm{C} \mathrm{NMR}\left(\mathrm{CDCl}_{3}\right) \delta-5.0$, $14.5,42.9,47.2,128.2,129.9,133.9,134.0,201.9,245.2$; MS $\mathrm{m} / \mathrm{z}$ (rel intensity) $234\left(\mathrm{M}^{+}, 8\right), 193$ (91), 178 (13), 163 (21), 152(15), 135 (100), 105 (18), 89 (13); HRMS calcd for $\mathrm{C}_{13} \mathrm{H}_{18} \mathrm{O}_{2^{-}}$ Si 234.1076, found 234.1079.

1-(Trimethylsilyl)-1,6-hexanedione (47). Method A. Dithiane 45 (320 mg, $1 \mathrm{mmol}$ ), prepared from alkylation of 2-(trimethylsilyl)-1,3-dithiane with 5-bromopentanal ethylene acetal, ${ }^{29}$ was stirred with $\mathrm{TsOH}(22 \mathrm{mg}, 0.12 \mathrm{mmol})$ in acetone $(5 \mathrm{~mL})$ at $25^{\circ} \mathrm{C}$ for $24 \mathrm{~h}$. The mixture was partitioned between $\mathrm{Et}_{2} \mathrm{O}(20 \mathrm{~mL})$ and $\mathrm{H}_{2} \mathrm{O}(10 \mathrm{~mL})$. The organic layer was washed with brine $(15 \mathrm{~mL} \times 2)$, dried $\left(\mathrm{Na}_{2} \mathrm{SO}_{4}\right)$, and concentrated. The residue was then treated with $\mathrm{HgO}(360 \mathrm{mg}, 1.66 \mathrm{mmol}$ ) and $\mathrm{BF}_{3}{ }^{\circ} \mathrm{OEt}_{2}(0.2 \mathrm{~mL}, 1.66 \mathrm{mmol})$ according to the general procedure to give 47 (111 mg, 60\%).

Method B. The crude 2-(4-bromobutyl)-2-(trimethylsilyl)1,3-dithiane (40), prepared from alkylation of 2-(trimethylsi|yl)-1,3-dithiane (2 g, $10.39 \mathrm{mmol}$ ) with 1,4-dibromobutane (1.24 mL, $10.5 \mathrm{mmol})$, was dissolved in THF $(15 \mathrm{~mL})$ and added to a solution of 2-lithio-1,3-dithiane (10.8 mmol) in THF (15 $\mathrm{mL}$ ) at $-20^{\circ} \mathrm{C}$ under $\mathrm{Ar}$. The reaction was stirred at $0{ }^{\circ} \mathrm{C}$ for $20 \mathrm{~min}$ and quenched by addition of aqueous $\mathrm{NH}_{4} \mathrm{Cl}$. The organic layer was taken up in EtOAc $(60 \mathrm{~mL})$ and washed with $\mathrm{H}_{2} \mathrm{O}(30 \mathrm{~mL} \times 2)$, brine $(30 \mathrm{~mL} \times 2)$, dried $\left(\mathrm{Na}_{2} \mathrm{SO}_{4}\right)$, and concentrated. The residue was treated with $\mathrm{HgO}(8.26 \mathrm{~g}, 38.1$ $\mathrm{mmol})$ and $\mathrm{BF}_{3} \cdot \mathrm{OEt}_{2}(4.69 \mathrm{~mL}, 38.1 \mathrm{mmol})$ according to the general procedure to give 47 (520 mg, 27\%).

45: An oil; TLC (EtOAc/hexane (10:90)) $\mathrm{R}_{\mathrm{f}}=0.24$; IR (neat) 2944, 1246, 1138, 1036, 944, 910, $842 \mathrm{~cm}^{-1}$; ${ }^{1 \mathrm{H}} \mathrm{NMR}\left(\mathrm{CDCl}_{3}\right)$ $\delta 0.15(\mathrm{~s}, 9 \mathrm{H}), 1.44-2.20(\mathrm{~m}, 10 \mathrm{H}), 2.39(\mathrm{dt}, \mathrm{J}=14.4,4.2 \mathrm{~Hz}$, $2 \mathrm{H}), 2.98(\mathrm{brt}, \mathrm{J}=14.4 \mathrm{~Hz}, 2 \mathrm{H}), 3.80-3.94(\mathrm{~m}, 4 \mathrm{H}), 4.84(\mathrm{t}$, $\mathrm{J}=4.5 \mathrm{~Hz}, 1 \mathrm{H}) ;{ }^{13} \mathrm{C} \mathrm{NMR}\left(\mathrm{CDCl}_{3}\right) \delta-2.5(\mathrm{q}, 3 \mathrm{C}), 23.3(\mathrm{t}, 2$ C), $24.5(\mathrm{t}), 25.1(\mathrm{t}), 27.5(\mathrm{t}), 33.7(\mathrm{t}), 37.1(\mathrm{t}), 38.6(\mathrm{~s}), 64.8(\mathrm{t}$, $2 \mathrm{C}), 104.5$ (d); MS m/ z (rel intensity) $320\left(\mathrm{M}^{+}, 6\right), 247$ (11), 215 (8), 185 (4), 153 (16), 139 (12), 73 (100); HRMS calcd for $\mathrm{C}_{14} \mathrm{H}_{28} \mathrm{O}_{2} \mathrm{~S}_{2} \mathrm{Si} 320.1300$, found 320.13026 . 47: An oil; TLC (EtOAc/hexane (5:95)) $\mathrm{R}_{\mathrm{f}}=0.11$; IR (neat) 2952, 2872, 1722, 1640, 1249, 845, $753 \mathrm{~cm}^{-1}$; ${ }^{1} \mathrm{H}$ NMR $\left(\mathrm{CDCl}_{3}\right) \delta 0.16(\mathrm{~s}, 9 \mathrm{H})$, 1.49-1.57 (m, $4 \mathrm{H}), 2.39(\mathrm{td}, \mathrm{J}=6.8,1.8 \mathrm{~Hz}, 2 \mathrm{H}), 2.59(\mathrm{t}, \mathrm{J}$ $=6.8 \mathrm{~Hz}, 2 \mathrm{H}), 9.71(\mathrm{t}, \mathrm{J}=1.8 \mathrm{~Hz}, 1 \mathrm{H}) ;{ }^{13} \mathrm{C} \mathrm{NMR}\left(\mathrm{CDCl}_{3}\right) \delta$ $-3.2(\mathrm{q}, 3 \mathrm{C}), 21.4(\mathrm{t}), 21.7(\mathrm{t}), 43.7(\mathrm{t}), 47.8(\mathrm{t}), 202.2(\mathrm{~d}), 247.5$ (s); $\mathrm{MS} \mathrm{m} / \mathrm{z}$ (rel intensity) $186\left(\mathrm{M}^{+}, 2\right), 171$ (6), 144 (5), 129 (8), 101 (6), 73 (100), 45 (25); HRMS calcd for $\mathrm{C}_{9} \mathrm{H}_{18} \mathrm{O}_{2} \mathrm{Si}$ 186.1077, found 186.1073.

1-(Dimethylphenylsilyl)-1,7-heptanedione (48). To a solution of $\mathbf{4 1}(2.25 \mathrm{~g}, 7.3 \mathrm{mmol})$ in dry THF $(8 \mathrm{~mL})$ was added dropwise at $0{ }^{\circ} \mathrm{C}$ a hexane solution of BuLi $(1.55 \mathrm{M}, 5.2 \mathrm{~mL})$. The resulting solution was stirred at $0{ }^{\circ} \mathrm{C}$ for $10 \mathrm{~min}$ followed by the addition of dimethylphenylchlorosilane $(1.34 \mathrm{~mL}, 8.03$ $\mathrm{mmol}$ ) in one portion. After stirring for another $10 \mathrm{~min}$ at 0 ${ }^{\circ} \mathrm{C}$, the reaction mixture was partitioned between ether (100 $\mathrm{mL})$ and water $(80 \mathrm{~mL})$. The organic layer was washed with brine $(50 \mathrm{~mL})$, dried $\left(\mathrm{MgSO}_{4}\right)$, and concentrated in vacuo. The residue was mixed with red $\mathrm{HgO}(6.3 \mathrm{~g}, 29.2 \mathrm{mmol})$, THF (30 $\mathrm{mL})$, and water $(6 \mathrm{~mL})$, followed by the addition of $\mathrm{BF}_{3} \cdot \mathrm{OEt}_{2}$ $(2.69 \mathrm{~mL}, 22.0 \mathrm{mmol})$ in one portion. The resulting mixture was stirred at room temperature for $0.5 \mathrm{~h}$, diluted with ether $(100 \mathrm{~mL})$, and filtered. The filtrate was washed with water $(50 \mathrm{~mL})$, brine $(50 \mathrm{~mL})$, dried $\left(\mathrm{MgSO}_{4}\right)$, and concentrated in vacuo. The residue was chromatographed on silica gel (EtOAcl hexane (1:9)) to give $\mathbf{4 8}$ (1.04 g, 55\%) as a light yellow liquid: IR (neat) 2934, 1717, 1633, 1423, 1247, 1168, 835, 780, 736, $701 \mathrm{~cm}^{-1}$; ${ }^{1} \mathrm{H}$ NMR $\left(\mathrm{CDCl}_{3}\right) \delta 0.46(\mathrm{~s}, 6 \mathrm{H}), 1.10-1.25(\mathrm{~m}, 2$ $\mathrm{H}), 1.35-1.60(\mathrm{~m}, 4 \mathrm{H}), 2.31(\mathrm{td}, \mathrm{J}=7.0,2.0 \mathrm{~Hz}, 2 \mathrm{H}), 2.54(\mathrm{t}$, $\mathrm{J}=7.0 \mathrm{~Hz}, 2 \mathrm{H}), 7.25-7.45(\mathrm{~m}, 3 \mathrm{H}), 7.45-7.60(\mathrm{~m}, 2 \mathrm{H}), 9.67$ $(\mathrm{t}, \mathrm{J}=2 \mathrm{~Hz}, 1 \mathrm{H}) ;{ }^{13} \mathrm{C} \mathrm{NMR}\left(\mathrm{CDCl}_{3}\right) \delta-4.9,21.7,28.5,43.5$, $48.2,128.1,129.8,133.8,134.4,202.4,246.0 ; \mathrm{MS} \mathrm{m} / \mathrm{z}$ (rel intensity) $262\left(\mathrm{M}^{+}, 100\right), 247$ (30), 209 (31), 191 (16), 185 (33) 163 (20), 115 (100), 105 (9), 75 (19), 55 (15); HRMS calcd for $\mathrm{C}_{15} \mathrm{H}_{22} \mathrm{O}_{2} \mathrm{Si} 262.1389$, found 262.1382 .

General Procedure for Reactions of Acyl Silanes with Samarium(II) Iodide. Samarium metal $(0.33 \mathrm{~g}, 2.1 \mathrm{mmol})$ was added under a flow of Ar to an oven-dried round-bottomed flask containing a magnetic stirring bar. The flask and samari um were gently flame-dried and cooled under Ar. THF $(20 \mathrm{~mL})$ was added followed by 1,2-diiodoethane $(0.5 \mathrm{~g}, 2$ $\mathrm{mmol}$ ), and the mixture was allowed to stir at room temerature for $2 \mathrm{~h}$. HMPA $(0.35 \mathrm{~mL}, 2 \mathrm{mmol})$ was added in appropriate cases, and the resulting purple solution was allowed to stir for $30 \mathrm{~min}$. Acyl silane $(1 \mathrm{mmol})$ in THF $(20 \mathrm{~mL})$ was added over a period of $10 \mathrm{~min}$. A proton source $(\mathrm{MeOH}$ or $\mathrm{t}-\mathrm{BuOH}$, $2 \mathrm{mmol}$ ) or alkylating agent (allyl bromide or benzyl bromide, $1.6 \mathrm{mmol}$ ) was added in appropriate cases. After complete addition, the mixture was stirred for $15 \mathrm{~min}$, quenched with $\mathrm{H}_{2} \mathrm{O}$ (2 drops), and filtered. The solvent was removed on rotary evaporation. The residue was passed through a short silica gel column to remove HMPA, and products were separated by silica gel chromatography using EtOAc/hexane as eluent.

General Procedure for Reactions of Acyl Silanes with Tributyltin Hydride. To a solution of acyl silane $(1.68 \mathrm{mmol})$ in deoxygenated benzene $(17 \mathrm{~mL})$ was added dropwise at 80 ${ }^{\circ} \mathrm{C}$ over $1 \mathrm{~h}$ a solution of $\mathrm{Bu}_{3} \mathrm{SnH}(0.68 \mathrm{~mL}, 2.52 \mathrm{mmol})$ and a catalytic amount of AIBN in deoxygenated benzene $(17 \mathrm{~mL})$. The resulting solution was stirred at $80{ }^{\circ} \mathrm{C}$ for another $1 \mathrm{~h}$ and concentrated in vacuo to give an oil. The oil was mixed with a few drops of $\mathrm{Et}_{3} \mathrm{~N}$ and chromatographed on silica gel to afford products.

$\alpha$-(Trimethylsilyl)benzyl alcohol (49) ${ }^{42}$ and $\alpha$-Phenylacetophenone (52).43 The reaction of phenyl trimethyl silyl ketone $2(178 \mathrm{mg}, 1 \mathrm{mmol})$ with $\mathrm{Sml}_{2}$ in THF at $28^{\circ} \mathrm{C}$ for $1 \mathrm{~h}$ gave 49 (113 mg, 63\%). The reaction in the presence of HMPA (0.35 mL, $2 \mathrm{mmol}$ ) gave 49 (92 mg, 47\%) and $\alpha$-phenylacetophenone (52, $54 \mathrm{mg}, 30 \%)$. Compound 49-d was obtained from the reaction of $\mathbf{2}$ with $\mathrm{Sml}_{2}$ in THF/HMPA/t-BuOD (2 equiv). 49: An oil; TLC (EtOAc/hexane (2:98)) $R_{f}=0.2 ;$ IR (neat) $3430,3061,2957,1679,1445,1245,997 \mathrm{~cm}^{-1}$; ${ }^{1} \mathrm{H}$ NMR $\left(\mathrm{CDCl}_{3}\right) \delta 0.00(\mathrm{~s}, 9 \mathrm{H}), 4.49(\mathrm{~s}, 1 \mathrm{H}), 7.15-7.28(\mathrm{~m}, 5 \mathrm{H})$; $\mathrm{MS}$ $\mathrm{m} / \mathrm{z}$ (rel intensity) $180\left(\mathrm{M}^{+}, 55\right), 165$ (65), $137(28), 122(20)$ 105 (15), 90 (12), 73 (100). 49-d: ${ }^{13} \mathrm{C} \mathrm{NMR}\left(\mathrm{CDCl}_{3}\right) \delta 69.9(\mathrm{~J} \mathrm{C-D}$ $=20.0 \mathrm{~Hz}$ ). MS m/ z (rel intensity) $181\left(\mathrm{M}^{+}, 16\right)$. 52: Solid,

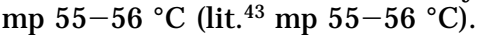

1-Phenyl-1-(trimethylsilyl)-3-butenol (50). The reaction of phenyl trimethylsilyl ketone $\mathbf{2}(178 \mathrm{mg}, 1 \mathrm{mmol})$ with $\mathrm{Sml}_{2}$ in THF/HMPA at $25^{\circ} \mathrm{C}$ for $15 \mathrm{~min}$, followed by al kylation with

(42) Wright, A.; West, R. J . Am. Chem. Soc. 1974, 96, 3220

(43) A commercially available compound. Beil. 7 (2), 368 
allyl bromide ( $0.09 \mathrm{~mL}, 1 \mathrm{mmol}$ ) for $2 \mathrm{~h}$, gave $\mathbf{5 0}$ (184 mg, 84\%). An oil; TLC (EtOAc/hexane (5:95)) $R_{f}=0.3$; IR (neat) 3512, 2951, 1592, 1486, 1437, 1244, $1033 \mathrm{~cm}^{-1} ;{ }^{1} \mathrm{H} \mathrm{NMR}\left(\mathrm{CDCl}_{3}\right) \delta$ $-0.03(\mathrm{~s}, 9 \mathrm{H}), 1.84(\mathrm{~s}, 1 \mathrm{H}), 2.49(\mathrm{dd}, \mathrm{J}=13.0,9.4 \mathrm{~Hz}, 1 \mathrm{H})$, $2.00(\mathrm{dd}, \mathrm{J}=13.0,4.6 \mathrm{~Hz}, 1 \mathrm{H}), 5.08-5.18(\mathrm{~m}, 2 \mathrm{H}), 5.37-$ $5.51(\mathrm{~m}, 1 \mathrm{H}), 7.09-7.29(\mathrm{~m}, 5 \mathrm{H}) ;{ }^{13} \mathrm{C} \mathrm{NMR}\left(\mathrm{CDCl}_{3}\right) \delta-4.1(\mathrm{q}$, 3 C), $41.2(\mathrm{t}), 70.4(\mathrm{~s}), 124.9$ (d, 2 C), $125.1(\mathrm{~d}), 127.9$ (d, 2 C), 132.7 (d), 145.6 (s); MS m/ z (rel intensity) $220\left(\mathrm{M}^{+}, 25\right), 219$ (100), 205 (25), 177 (10), 129 (80), 105 (45), 73 (50); HRMS calcd for $\mathrm{C}_{13} \mathrm{H}_{20} \mathrm{OSi} 219.1205$, found 219.1195.

1,2-Diphenyl-1-(trimethylsilyl)ethanol (51). The reaction of phenyl trimethylsilyl ketone $\mathbf{2}(90 \mathrm{mg}, 0.5 \mathrm{mmol})$ with $\mathrm{Sml}_{2}$ in THF/HMPA at $25^{\circ} \mathrm{C}$ for $15 \mathrm{~min}$, followed by alkylation with benzyl bromide $(0.1 \mathrm{~mL}, 0.8 \mathrm{mmol})$ for $2 \mathrm{~h}$, gave 51 (123 mg, 91\%). An oil; TLC (EtOAc/hexane (5:95)) $\mathrm{R}_{\mathrm{f}}=0.15$; IR (neat) 3526, 3062, 2954, 1590, 1486, 1241, $1170 \mathrm{~cm}^{-1}$; ${ }^{1} \mathrm{H}$ NMR $\left(\mathrm{CDCl}_{3}\right) \delta 0.04(\mathrm{~s}, 9 \mathrm{H}), 1.53(\mathrm{~s}, 1 \mathrm{H}), 3.16(\mathrm{~d}, \mathrm{~J}=13.6 \mathrm{~Hz}, 1$ $\mathrm{H}), 3.50(\mathrm{~d}, \mathrm{~J}=13.6 \mathrm{~Hz}, 1 \mathrm{H}), 6.91-7.30(\mathrm{~m}, 10 \mathrm{H}) ;{ }^{13} \mathrm{C} N M R$ $\left(\mathrm{CDCl}_{3}\right) \delta-4.0(\mathrm{q}, 3 \mathrm{C}), 42.6(\mathrm{t}), 71.7(\mathrm{~s}), 124.9$ (d, $\left.2 \mathrm{C}\right), 125.0$ (d), 126.5 (d), 127.7 (d, 2 C), 128.0 (d, 2 C), 130.5 (d, 2 C), 135.5 (s), 145.5 (s); MS m/ z (rel intensity) 270 ( $\left.\mathrm{M}^{+}, 45\right), 253$ (5), 179 (48), 165 (24), 105 (100), 91 (14), 73 (22); HRMS calcd for $\mathrm{C}_{17} \mathrm{H}_{22} \mathrm{OSi} 270.1440$, found 270.1444 .

1-(Trimethylsilyl)hexanol (53). ${ }^{6}$ The reaction of 1-(trimethylsilyl)-1-hexanone (4) (172 $\mathrm{mg}, 1 \mathrm{mmol}$ ) with $\mathrm{Sml}_{2}$ in THF at $28{ }^{\circ} \mathrm{C}$ for $1 \mathrm{~h}$ gave $53(87 \mathrm{mg}, 50 \%)$. An oil; TLC (EtOAc/hexane (5:95)) $\mathrm{R}_{\mathrm{f}}=0.2 ;{ }^{1} \mathrm{H}$ NMR $\left(200 \mathrm{MHz}, \mathrm{CDCl}_{3}\right) \delta$ $0.01(\mathrm{~s}, 9 \mathrm{H}), 0.87(\mathrm{t}, \mathrm{J}=6.6 \mathrm{~Hz}, 3 \mathrm{H}), 1.23-1.33(\mathrm{~m}, 6 \mathrm{H})$, $1.46-1.51(\mathrm{~m}, 2 \mathrm{H}), 3.27(\mathrm{t}, \mathrm{J}=6.0 \mathrm{~Hz}, 1 \mathrm{H})$

N-[3-Hydroxyl-3-(trimethylsilyl)propyl]pyrrolidine2,5-dione (54). The reaction of $\mathrm{N}$-[3-0xo-3-(trimethylsilyl)propyl ]pyrroline-2,5-dione (14) (113 mg, $0.5 \mathrm{mmol}$ ) with $\mathrm{Sml} 2$ in THF at $28^{\circ} \mathrm{C}$ for $1 \mathrm{~h}$ gave $54(57 \mathrm{mg}, 50 \%)$. Solid, $\mathrm{mp} 78-$ $79{ }^{\circ} \mathrm{C}$; TLC (EtOAc/hexane (70:30)) $\mathrm{R}_{\mathrm{f}}=0.15$; IR (KBr) 3430, $2980,1750,1700,1450,1240,880 \mathrm{~cm}^{-1} ;{ }^{1} \mathrm{H}$ NMR $\left(\mathrm{CDCl}_{3}\right) \delta$ $-0.22(\mathrm{~s}, 9 \mathrm{H}), 1.58-1.70(\mathrm{~m}, 2 \mathrm{H}), 2.72(\mathrm{~s}, 4 \mathrm{H}), 2.94-3.02$ $(\mathrm{m}, 2 \mathrm{H}), 3.66-3.73(\mathrm{~m}, 2 \mathrm{H}) ;{ }^{13} \mathrm{C} N M R\left(\mathrm{CDCl}_{3}\right) \delta-4.1(\mathrm{q}, 3$ C), 28.1 (t, 2 C), 31.1 (t), $35.6(\mathrm{t}), 60.7$ (d), 178.0 (s, 2 C); MS $\mathrm{m} / \mathrm{z}$ (rel intensity) $230\left(\mathrm{M}^{+}+1,2\right), 214$ (100), 199 (4), 185 (10), 156 (25), 113 (28), 73 (30); HRMS calcd for $\mathrm{C}_{9} \mathrm{H}_{16} \mathrm{NO}_{3} \mathrm{Si}$ 214.0899, found 214.0907

3-(2-Bromophenyl)-1-(trimethylsilyl)propanol (55). The reaction of 3-(2-bromophenyl)-1-(trimethylsilyl)propanone 15 (110 mg, $0.38 \mathrm{mmol}$ ) with $\mathrm{Sml}_{2}$ in THF/HMPA/M eOH at 18 ${ }^{\circ} \mathrm{C}$ for $1 \mathrm{~h}$ gave 55 (70 mg, 63\%). An oil; TLC (E tOAc/hexane $(10: 90)) R_{f}=0.25$; IR (neat) 3418, 3058, 1694, 1587, 1560, 1463, $1245 \mathrm{~cm}^{-1} ;{ }^{1} \mathrm{H}$ NMR $\left(\mathrm{CDCl}_{3}\right) \delta 0.03(\mathrm{~s}, 9 \mathrm{H}), 1.25(\mathrm{br} \mathrm{s}, 1 \mathrm{H})$, 1.75-1.85 (m, 2 H), 2.72-2.80 (m, $1 \mathrm{H}), 2.97-3.02(\mathrm{~m}, 1 \mathrm{H})$, $3.31(\mathrm{dd}, \mathrm{J}=9.3,4.0 \mathrm{~Hz}, 1 \mathrm{H}), 7.01-7.06(\mathrm{~m}, 1 \mathrm{H}), 7.21-7.23$ $(\mathrm{m}, 2 \mathrm{H}), 7.50(\mathrm{~d}, \mathrm{~J}=7.8 \mathrm{~Hz}, 1 \mathrm{H}) ;{ }^{13} \mathrm{C} \mathrm{NMR}\left(\mathrm{CDCl}_{3}\right) \delta-3.9$ (q, 3 C), 33.5 (t), 33.7 (t), 65.4 (d), 124.0 (s), 127.4 (d), 127.5 (d), 130.4 (d), 132.7 (d), 141.4 (s); MS m/ z (rel intensity) 287 $\left(\mathrm{M}^{+}-1\right.$ 1, 3), 285 (2), 226 (2), 224 (3), 198 (6), 196 (7), 73 (100); HRMS calcd for $\mathrm{C}_{12} \mathrm{H}_{18}$ BrOSi 287.0289, found 287.0303 .

3-(2-Bromophenyl)-1-(diphenylmethylsilyl)propanol (56). The reaction of 3-(2-bromophenyl)-1-(diphenylmethylsilyl)propanone (16) (146 mg, $0.356 \mathrm{mmol}$ ) with $\mathrm{Sml}_{2}$ in THF/ HMPA at $28{ }^{\circ} \mathrm{C}$ for $1 \mathrm{~h}$ gave $56(75 \mathrm{mg}, 52 \%)$. An oil; TLC (EtOAc/hexane (5:95)) $\mathrm{R}_{\mathrm{f}}=0.25$; IR (neat) 3442, 3066, 2922, $1422,1249,1110,789 \mathrm{~cm}^{-1} ;{ }^{1} \mathrm{H} N M R\left(\mathrm{CDCl}_{3}\right) \delta 0.60(\mathrm{~s}, 3 \mathrm{H})$, 1.86-1.98 (m, 2 H), 2.77-2.84 (m, $1 \mathrm{H}), 2.99-3.05(\mathrm{~m}, 1 \mathrm{H})$, $3.89-3.93(\mathrm{~m}, 1 \mathrm{H}), 7.00-7.62(\mathrm{~m}, 14 \mathrm{H}) ;{ }^{3} \mathrm{C} \mathrm{NMR}\left(\mathrm{CDCl}_{3}\right) \delta$ -6.7 (q), 33.6 (t, 2 C), 63.9 (d), 124.5 (s), 127.4 (d), 127.5 (d), 128.0 (d, 4 C), 129.6 (d, 2 C), 130.5 (d), 132.7 (d), 134.5 (s, 2 C), 134.9 (d, 2 C), 135.0 (d, 2 C), 141.2 (s); FAB-MS m/ z (rel intensity) 412 ( $\mathrm{M}^{+}, 1$ ), 395 (3), 333 (7), 273 (8), 257 (2), 197 (100), 195 (5); HRMS calcd for $\mathrm{C}_{21} \mathrm{H}_{20} \mathrm{BrOSi} 397.0446$, found 397.0422.

1-(Dimethylphenylsilyl)cyclopentanol (57). The reaction of 5-bromo-1-(dimethyl phenylsilyl)pentanone (17) $(180 \mathrm{mg}$, $0.6 \mathrm{mmol}$ ) with $\mathrm{Sml}{ }_{2}$ in $\mathrm{THF}$ at $18^{\circ} \mathrm{C}$ for $1 \mathrm{~h}$ gave $57(62 \mathrm{mg}$, 47\%). An oil; TLC (EtOAc/hexane (5:95)) $R_{f}=0.15$; IR (neat) 3422, 2958, 2906, 2853, 1427, 1251, $1111 \mathrm{~cm}^{-1} ;{ }^{1 H} \mathrm{NMR}$ $\left(\mathrm{CDCl}_{3}\right) \delta 0.33(\mathrm{~s}, 6 \mathrm{H}), 1.50-1.82(\mathrm{~m}, 9 \mathrm{H}), 7.32-7.36(\mathrm{~m}, 3$ $\mathrm{H}), 7.55-7.59(\mathrm{~m}, 2 \mathrm{H}) ;{ }^{13} \mathrm{C}$ NMR $\left(\mathrm{CDCl}_{3}\right) \delta-5.6(\mathrm{q}, 2 \mathrm{C}), 23.7$ (t, 2 C), 37.6 (t, 2 C), 75.0 (s), 127.8 (d, 2 C), 129.2 (d), 134.3 (d, 2 C), 136.8 (s); MS m/ z (rel intensity) $219\left(M^{+}-1,1\right), 205$
(25), 187 (6), 135 (100), 121 (9), 75 (60), 58 (9); HRMS calcd for $\mathrm{C}_{13} \mathrm{H}_{20} \mathrm{OSi} 220.1283$, found 220.1268 .

1-(tert-Butyldimethylsilyl)cyclohexanol (58) and 6-Bromo-1-(tert-butyldimethylsilyl)hexanol (59). The reaction of 6-bromo-1-(tert-butyl dimethylsilyl)hexanone (18) $(140 \mathrm{mg}$, $0.47 \mathrm{mmol}$ ) with $\mathrm{Sml}_{2}$ in THF at $26^{\circ} \mathrm{C}$ for $1 \mathrm{~h}$ gave $58(45 \mathrm{mg}$ 45\%) and 59 (24 mg, 17\%). 58: An oil; TLC (EtOAc/hexane $(5: 95)) R_{f}=0.28$; IR (neat) 3492, 2929, 2854, 1243, 1127, 1005, $830 \mathrm{~cm}^{-1} ;{ }^{1} \mathrm{H} N M R\left(\mathrm{CDCl}_{3}\right) \delta-0.04(\mathrm{~s}, 6 \mathrm{H}), 0.94(\mathrm{~s}, 9 \mathrm{H}), 1.01$ (br s, $1 \mathrm{H}), 1.42-1.78(\mathrm{~m}, 10 \mathrm{H}) ;{ }^{13} \mathrm{C} \mathrm{NMR}\left(\mathrm{CDCl}_{3}\right) \delta-8.0(\mathrm{q}$ $2 \mathrm{C}), 17.9$ (s), 19.9 (t, 2 C), 26.0 (t), 27.9 (q, 3 C), 34.1 (t, 2 C), 67.3 (s); MS m/ z (rel intensity) $213\left(\mathrm{M}^{+}-1,5\right), 185$ (15), 149 (22), 129 (36), 111 (51), 97 (65), 57 (100); HRMS calcd for $\mathrm{C}_{12} \mathrm{H}_{26} \mathrm{OSi}$ 214.1753, found 214.1747. 59: An oil; TLC (EtOAC hexane (5:95)) $\mathrm{R}_{\mathrm{f}}=0.14$; ${ }^{1} \mathrm{H} \mathrm{NMR}\left(\mathrm{CDCl}_{3}\right) \delta-0.08(\mathrm{~s}, 3 \mathrm{H})$, $-0.01(\mathrm{~s}, 3 \mathrm{H}), 0.91(\mathrm{~s}, 9 \mathrm{H}), 1.35-1.87(\mathrm{~m}, 8 \mathrm{H}), 3.38(\mathrm{t}, \mathrm{J}=$ $6.8 \mathrm{~Hz}, 2 \mathrm{H}$ ), $3.70(\mathrm{t}, \mathrm{J}=6.0 \mathrm{~Hz}, 1 \mathrm{H}$ ); MS m/ z (rel intensity) $215\left(\mathrm{M}^{+}-\mathrm{Br}, 1\right), 180$ (1), 139 (4), 115 (8), 99 (3), 73 (100), 55 (72); HRMS calcd for $\mathrm{C}_{12} \mathrm{H}_{26} \mathrm{BrOSi} 295.0915$, found 295.0924 .

7-Bromo-1-(trimethylsilyl)heptanol (60). The reaction of 7-bromo-1-(trimethylsilyl)heptanone (19) (110 mg, 0.41 $\mathrm{mmol}$ ) with $\mathrm{Sml} 2$ in THF at $28{ }^{\circ} \mathrm{C}$ for $12 \mathrm{~h}$ gave 60 (60 mg, $55 \%)$. An oil; TLC (EtOAc/hexane (10:90)) $R_{f}=0.33$; IR (neat) $3409,2926,2853,1457,1244,839,749 \mathrm{~cm}^{-1} ;{ }^{1} \mathrm{H} N M R\left(\mathrm{CDCl}_{3}\right)$ $\delta 0.00(\mathrm{~s}, 9 \mathrm{H}), 1.10-1.55(\mathrm{~m}, 9 \mathrm{H}), 1.82(\mathrm{q}, \mathrm{J}=6.8 \mathrm{~Hz}, 2 \mathrm{H})$, $3.25(\mathrm{t}, \mathrm{J}=6.8 \mathrm{~Hz}, 2 \mathrm{H}), 3.37(\mathrm{t}, \mathrm{J}=6.8 \mathrm{~Hz}, 2 \mathrm{H}) ;{ }^{13} \mathrm{C} \mathrm{NMR}$ $\left(\mathrm{CDCl}_{3}\right) \delta-3.9(\mathrm{q}, 3 \mathrm{C}), 26.5(\mathrm{t}), 28.0(\mathrm{t}), 28.6(\mathrm{t}), 32(\mathrm{t}), 33.3$ (t), $33.8(\mathrm{t}), 65.9(\mathrm{~d}) ; \mathrm{MS} \mathrm{m} / \mathrm{z}$ (rel intensity) $267\left(\mathrm{M}^{+}, 12\right), 229$ (2), 183 (1), 133 (15), 117 (50), 95 (25), 73 (100); HRMS calcd for $\mathrm{C}_{10} \mathrm{H}_{22} \mathrm{BrOSi} 267.0603$, found 267.0607 .

1-(Trimethylsilyl)-5-hexenol (61) and 1-(Trimethylsilyl)-2-methylcyclopentanol (65). The reaction of 1-(trimethyl silyl)-5-hexenone (20) (70 mg, $0.4 \mathrm{mmol}$ ) with $\mathrm{Sml}_{2}$ in $\mathrm{THF} / \mathrm{t}-\mathrm{BuOH}(0.8 \mathrm{mmol}) / \mathrm{HMPA}(2 \mathrm{mmol})$ at $28{ }^{\circ} \mathrm{C}$ gave 61 (22 $\mathrm{mg}, 32 \%)$ and 65 (18 mg, 26\%). 61: An oil; TLC (EtOACl hexane (5:95)) $R_{\mathrm{f}}=0.2$; I $\mathrm{R}$ (neat) 3402, 3077, 2953, 1632, 1436, $1245,992 \mathrm{~cm}^{-1} ;{ }^{1} \mathrm{H}$ NMR $\left(\mathrm{CDCl}_{3}\right) \delta 0.02(\mathrm{~s}, 9 \mathrm{H}), 1.36-1.70$ $(\mathrm{m}, 4 \mathrm{H}), 2.01-2.10(\mathrm{~m}, 2 \mathrm{H}), 3.28(\mathrm{t}, \mathrm{J}=6.8 \mathrm{~Hz}, 1 \mathrm{H}), 4.90$ $5.05(\mathrm{~m}, 2 \mathrm{H}), 5.70-5.90(\mathrm{~m}, 1 \mathrm{H}) ;{ }^{13} \mathrm{C} \mathrm{NMR}\left(\mathrm{CDCl}_{3}\right) \delta-3.9(\mathrm{q}$, $3 \mathrm{C}), 26.0(\mathrm{t}), 32.9(\mathrm{t}), 33.6(\mathrm{t}), 65.9(\mathrm{~d}), 114.5(\mathrm{t}), 138.8(\mathrm{~d}) ; \mathrm{MS}$ $\mathrm{m} / \mathrm{z}$ (rel intensity) $172\left(\mathrm{M}^{+}, 2\right), 157$ (3), 141 (2), 129 (5), 98 (68), 73 (95), 67 (100); HRMS calcd for $\mathrm{C}_{9} \mathrm{H}_{20} \mathrm{OSi} 172.1283$, found 172.1283. 65: An oil; TLC (EtOAc/hexane (5:95)) $R_{f}=$ 0.25 ; IR (neat) 3450, 2962, 1457, 1371, 1245, 1205, $930 \mathrm{~cm}^{-1}$ ${ }^{1} \mathrm{H}$ NMR $\left(\mathrm{CDCl}_{3}\right) \delta 0.08(\mathrm{~s}, 9 \mathrm{H}), 0.87(\mathrm{~d}, \mathrm{~J}=6.8 \mathrm{~Hz}, 3 \mathrm{H})$, 1.10-2.05 (m, 7 H); ${ }^{13} \mathrm{C} \mathrm{NMR}\left(\mathrm{CDCl}_{3}\right) \delta-2.4(\mathrm{q}, 3 \mathrm{C}), 18.9(\mathrm{q})$, $21.4(\mathrm{t}), 32.2(\mathrm{t}), 35.2(\mathrm{t}), 46.2(\mathrm{~d}) ;{ }^{13} \mathrm{C}$ NMR (acetone- $\left.\mathrm{d}_{6}\right) \delta-2.0$ $(q, 3$ C), $19.1(q), 22.0(t), 32.9(t), 35.5(t), 46.8(d), 77.9(s)$; MS m/ z (rel intensity) $172\left(\mathrm{M}^{+}, 1\right), 155$ (8), 127 (6), 113 (2), 98 (10), 90 (26), 67 (100); HRMS calcd for $\mathrm{C}_{9} \mathrm{H}_{19} \mathrm{OSi}$ 171.1205, found 171.1185 .

1-(Diphenylmethylsilyl)-5-hexenol (62) and 1-(Diphenylmethylsilyl)-2-methylcyclopentanol (66). The reaction of 1-(diphenylmethylsilyl)-5-hexenone (21) $(100 \mathrm{mg}, 0.34 \mathrm{mmol}$ ) with $\mathrm{Sml}_{2}$ in THF/HMPA ( $\left.2 \mathrm{mmol}\right)$ for $1 \mathrm{~h}$ gave 62 (14 mg, 20\%), trans-66 (20 mg, 28\%), and cis-66 (20 mg, 28\%). Compound $\mathbf{6 2 - d}$ was obtained from the reaction of $\mathbf{2 1}$ with $\mathrm{Sml}_{2}$ in THF/HMPA/t-BuOD (3 equiv). 62: An oil; TLC (EtOAc/hexane (5:95)) $R_{f}=0.15$; IR (neat) 3445, 3070, 2929, $1634,1250,1188,1110 \mathrm{~cm}^{-1} ;{ }^{1} \mathrm{H}$ NMR $\left(\mathrm{CDCl}_{3}\right) \delta 0.60(\mathrm{~s}, 3 \mathrm{H})$, $1.13-2.09(\mathrm{~m}, 7 \mathrm{H}), 3.89(\mathrm{t}, \mathrm{J}=6.8 \mathrm{~Hz}, 1 \mathrm{H}), 4.89-5.00(\mathrm{~m}, 2$ $\mathrm{H}), 5.66-5.87(\mathrm{~m}, 1 \mathrm{H}) 7.31-7.44(\mathrm{~m}, 6 \mathrm{H}), 7.56-7.64(\mathrm{~m}, 4$ $\mathrm{H}) ;{ }^{13} \mathrm{C} \mathrm{NMR}\left(\mathrm{CDCl}_{3}\right) \delta-6.7(\mathrm{q}), 26.1(\mathrm{t}), 32.8(\mathrm{t}), 33.4(\mathrm{t}), 64.4$ (d), $114.5(\mathrm{t}), 127.9(\mathrm{~d}, 4 \mathrm{C}), 129.5(\mathrm{~d}, 2 \mathrm{C}), 134.9(\mathrm{~d}, 2 \mathrm{C}), 135.0$ (d, 4 C), 138.7 (d); MS m/ z (rel intensity) $296\left(M^{+}, 2\right), 281$ (36), 199 (100), 197 (95), 158 (6), 137 (46), 67 (12); HRMS calcd for $\mathrm{C}_{19} \mathrm{H}_{24} \mathrm{OSi}$ 296.1596, found 296.1589. 62-d: ${ }^{13} \mathrm{C} \mathrm{NMR}\left(\mathrm{CDCl}_{3}\right)$ $\delta 63.8\left(\mathrm{~J} \mathrm{C-D}=20.0 \mathrm{~Hz}\right.$ ). MS m/ z (rel intensity) $297\left(\mathrm{M}^{+}, 4\right)$. trans-66: An oil; TLC (EtOAc/hexane (5:95)) $\mathrm{R}_{\mathrm{f}}=0.2$; HPLC (EtOAc/hexane (2:98)) $t_{R}=10.0$ min (Hibar Lichrosorb Si 60 $(7 \mu \mathrm{m})$ col umn $(25 \mathrm{~cm} \times 1 \mathrm{~cm}))$; IR (neat) 3449, 3068, 2957, $1582,1250,1186,1106 \mathrm{~cm}^{-1}$; ${ }^{1} \mathrm{H}$ NMR $\left(\mathrm{CDCl}_{3}\right) \delta 0.62(\mathrm{~s}, 3 \mathrm{H})$, $0.81(\mathrm{~d}, \mathrm{~J}=6.8 \mathrm{~Hz}, 3 \mathrm{H}), 1.40-1.96(\mathrm{~m}, 7 \mathrm{H}) 7.33-7.40(\mathrm{~m}, 6$ $\mathrm{H})$, 7.65-7.69 (m, $4 \mathrm{H}) ;{ }^{13} \mathrm{C} \mathrm{NMR}\left(\mathrm{CDCl}_{3}\right) \delta-5.7$ (q), $14.3(\mathrm{q})$, $22.3(\mathrm{t}), 32.5(\mathrm{t}), 39.5(\mathrm{t}), 42.2(\mathrm{~d}), 127.8(\mathrm{~d}, 4 \mathrm{C}), 129.3(\mathrm{~d}, 2 \mathrm{C})$, 135.2 (d, 4 C), 135.3 (s, 2 C); MS (rel intensity) m/ z $296\left(\mathrm{M}^{+}\right.$ 1), 281 (20), 214 (8), 197 (100), 158 (50), 137 (70), 120 (20) 
HRMS calcd for $\mathrm{C}_{19} \mathrm{H}_{24} \mathrm{OSi} 296.1596$, found 296.1595. cis-66: An oil; TLC (EtOAc/hexane (5:95)) $R_{f}=0.2 ;$ HPLC (EtOAd hexane $(2: 98)) t_{R}=11.3 \mathrm{~min}$ (Hibar Lichrosorb Si $60(7 \mu \mathrm{m})$ column $(25 \mathrm{~cm} \times 1 \mathrm{~cm})) ;{ }^{1} \mathrm{H} N M R\left(\mathrm{CDCl}_{3}\right) \delta 0.67(\mathrm{~s}, 3 \mathrm{H}), 0.72$ $(\mathrm{d}, \mathrm{J}=7.2 \mathrm{~Hz}, 3 \mathrm{H}), 1.18-2.29(\mathrm{~m}, 7 \mathrm{H}) 7.31-7.38(\mathrm{~m}, 6 \mathrm{H})$, 7.56-7.61 (m, $2 \mathrm{H}), 7.70-7.79(\mathrm{~m}, 2 \mathrm{H}) ;{ }^{13} \mathrm{C} \mathrm{NMR}\left(\mathrm{CDCl}_{3}\right) \delta$ $-4.1(\mathrm{q}), 19.4(\mathrm{q}), 21.5(\mathrm{t}), 32.1(\mathrm{t}), 36.3(\mathrm{t}), 45.5(\mathrm{~d}), 79.3(\mathrm{~s})$, 127.8 (d, 4 C), 129.3 (d, 2 C), 135.2 (d, 4 C), 135.5 (s, 2 C); MS $\mathrm{m} / \mathrm{z}$ (rel intensity) $296\left(\mathrm{M}^{+}, 1\right), 281$ (20), 214 (8), 197 (100), 158 (50), 137 (70), 120 (20); HRMS calcd for $\mathrm{C}_{19} \mathrm{H}_{24} \mathrm{OSi}$ 296.1596, found 296.1589.

4-(Diphenylmethylsilyl)-1,8-nonadien-4-ol (63). The solution of 21 (100 mg, $0.34 \mathrm{mmol})$ and allyl bromide $(0.035$ $\mathrm{mL}, 0.4 \mathrm{mmol}$ ) was treated with $\mathrm{Sml}_{2}(1 \mathrm{mmol})$ in THF/HMPA at $32{ }^{\circ} \mathrm{C}$ for $2 \mathrm{~h}$ gave 63 (96 mg, 84\%). An oil; TLC (EtOAd hexane (5:95)) $R_{f}=0.25$; IR (neat) 3555, 3069, 2935, 1632, $1423,1250,1105 \mathrm{~cm}^{-1}$; ${ }^{1} \mathrm{H}$ NMR $\left(\mathrm{CDCl}_{3}\right) \delta 0.66(\mathrm{~s}, 3 \mathrm{H}), 1.26-$ $1.40(\mathrm{~m}, 3 \mathrm{H}), 1.63-1.72(\mathrm{~m}, 2 \mathrm{H}), 1.92(\mathrm{q}, \mathrm{J}=6.8 \mathrm{~Hz}, 2 \mathrm{H})$, $2.45(\mathrm{~d}, \mathrm{~J}=7.5 \mathrm{~Hz}, 2 \mathrm{H}), 4.86-5.08(\mathrm{~m}, 4 \mathrm{H}), 5.60-5.79(\mathrm{~m}, 2$ $\mathrm{H}), 7.33-7.41(\mathrm{~m}, 6 \mathrm{H}), 7.70-7.73(\mathrm{~m}, 4 \mathrm{H}) ;{ }^{13} \mathrm{C} \mathrm{NMR}\left(\mathrm{CDCl}_{3}\right)$ $\delta-5.0(\mathrm{q}), 22.8(\mathrm{t}), 34.2(\mathrm{t}), 37.4(\mathrm{t}), 42.0(\mathrm{t}), 69.0(\mathrm{~s}), 114.5(\mathrm{t})$, $118.8(\mathrm{t}), 127.8(\mathrm{~d}, 4 \mathrm{C}), 129.3(\mathrm{~d}, 2 \mathrm{C}), 133.4(\mathrm{~d}), 135.2(\mathrm{~s}, 2 \mathrm{C})$, 135.4 (d, 4 C), 138.5 (d); MS m/ z (rel intensity) $336\left(M^{+}, 18\right)$, 321 (40), 307 (25), 295 (40), 245 (28), 197 (100), 137 (80); HRMS calcd for $\mathrm{C}_{22} \mathrm{H}_{28} \mathrm{OSi} 336.1909$, found 336.1920.

2-(Diphenylmethyl)-1-phenyl-6-hepten-2-ol (64). The solution of $\mathbf{2 1}$ ( $70 \mathrm{mg}, 0.238 \mathrm{mmol}$ ) and benzyl bromide (0.035 $\mathrm{mL}, 0.3 \mathrm{mmol})$ was treated with $\mathrm{Sml}_{2}(2 \mathrm{mmol})$ in THF/HMPA at $32{ }^{\circ} \mathrm{C}$ for $2 \mathrm{~h}$ gave $\mathbf{6 4}$ (73 mg, 79\%). An oil; TLC (EtOAd hexane (2:98)) $R_{f}=0.15$; IR (neat) 3536, 3067, 2934, 1633, $1423,1251,1107 \mathrm{~cm}^{-1} ;{ }^{1} \mathrm{H}$ NMR $\left(\mathrm{CDCl}_{3}\right) \delta 0.62(\mathrm{~s}, 3 \mathrm{H}), 1.23$ $(\mathrm{s}, 1 \mathrm{H}), 1.29-1.60(\mathrm{~m}, 4 \mathrm{H}), 1.83-1.93(\mathrm{q}, \mathrm{J}=6.8 \mathrm{~Hz}, 2 \mathrm{H})$, $2.92(\mathrm{~d}, \mathrm{~J}=13.4 \mathrm{~Hz}, 1 \mathrm{H}), 3.12(\mathrm{~d}, \mathrm{~J}=13.4 \mathrm{~Hz}, 1 \mathrm{H}), 4.80-$ $4.89(\mathrm{~m}, 2 \mathrm{H}), 5.54-5.71(\mathrm{~m}, 1 \mathrm{H}), 7.06-7.42(\mathrm{~m}, 11 \mathrm{H}), 7.74-$ $7.79(\mathrm{~m}, 4 \mathrm{H}) ;{ }^{13} \mathrm{C} \mathrm{NMR}\left(\mathrm{CDCl}_{3}\right) \delta-5.2(\mathrm{q}), 23.7(\mathrm{t}), 34.1(\mathrm{t})$, $37.6(\mathrm{t}), 42.9(\mathrm{t}), 69.6(\mathrm{~s}), 114.4(\mathrm{t}), 126.4(\mathrm{~d}), 127.7(\mathrm{~d}, 4 \mathrm{C})$, 128.0 (d, 2 C), 129.2 (d, 2 C), 130.8 (d, 2 C), 135.4 (d, 4 C), 135.5 (d), 136.2 (d, 2 C), 138.3 (d); MS m/ z (rel intensity) 386 $\left(\mathrm{M}^{+}, 75\right), 371$ (100), 330 (9), 315 (20), 293 (30), 197 (25), 137 (25)

2-(Diphenylmethylsilyl)-1-[2-(diphenylmethylsilyl)-2hydroxycyclopentyl]-6-hepten-2-ol (67). The reaction of 21 (200 mg, $0.68 \mathrm{mmol})$ with $\mathrm{Sml}_{2}(2 \mathrm{mmol})$ in THF $(27 \mathrm{~mL})$ gave 62 (26 mg, 13\%), 66 (36 mg, 18\%; cis/trans = 46:54) and 67 (76 mg, 38\%; diastereomers a/b/c = 44:44:12). I somer a was isolated by column chromatography on silica gel, and pure isomer b was obtained by HPLC. I somer a: An oil; TLC (EtOAc/hexane (10:90)) $\mathrm{R}_{\mathrm{f}}=0.27$; IR (neat) 3573, 3066, 2938, 1422, 1250, 1106, $699 \mathrm{~cm}^{-1}$; ${ }^{1} \mathrm{H}$ NMR $\left(\mathrm{CDCl}_{3}\right) \delta 0.49(\mathrm{~s}, 3 \mathrm{H})$, $0.50(\mathrm{~s}, 3 \mathrm{H}), 0.91-1.84(\mathrm{~m}, 15 \mathrm{H}), 2.09-2.17(\mathrm{~m}, 2 \mathrm{H}), 4.78-$ $4.84(\mathrm{~m}, 2 \mathrm{H}), 5.50-5.61(\mathrm{~m}, 1 \mathrm{H}), 7.27-7.39(\mathrm{~m}, 12 \mathrm{H}), 7.55-$ $7.64(\mathrm{~m}, 8 \mathrm{H}) ;{ }^{13} \mathrm{C}$ NMR $\left(\mathrm{CDCl}_{3}\right) \delta-5.4(\mathrm{q}),-5.2(\mathrm{q}), 22.6(\mathrm{t})$, $24.0(\mathrm{t}), 32.7(\mathrm{t}), 34.1(\mathrm{t}), 37.6(\mathrm{t}), 38.3(\mathrm{t}), 38.8(\mathrm{t}), 41.7(\mathrm{~d})$, 70.1 (s), 77.8 (s), 114.4 (t), 127.7 (d, 4 C), 127.8 (d,4 C), 129.2 (d, 2 C), 129.3 (d, 2 C), 133.9 (s), 135.2 (d, 2 C), 135.3 (d, 4 C), 135.4 (d, 2 C), 135.5 (s, 2 C), 135.7 (s), 138.3 (d); FAB-MS m/ z (rel intensity) 590 (M+, 0.2), 571 (0.6), $511(0.6), 375$ (10), 333 (18), 196 (100), 137 (72); HRMS calcd for $\mathrm{C}_{38} \mathrm{H}_{46} \mathrm{O}_{2} \mathrm{Si}_{2}$ 590.3036, found 590.3036. I somer b: An oil; TLC (EtOAc/hexane (10: 90)) $R_{f}=0.12$; IR (neat) 3576, 3066, 2938, 1422, 1249, 1106, $700 \mathrm{~cm}^{-1}$; ${ }^{1} \mathrm{H}$ NMR $\left(\mathrm{CDCl}_{3}\right) \delta 0.38(\mathrm{~s}, 3 \mathrm{H}), 0.57(\mathrm{~s}, 3 \mathrm{H}), 0.90-$ $1.10(\mathrm{~m}, 4 \mathrm{H}), 1.41-2.00(\mathrm{~m}, 13 \mathrm{H}), 4.77-4.83(\mathrm{~m}, 2 \mathrm{H}), 5.50$ $5.54(\mathrm{~m}, 1 \mathrm{H}), 7.26-7.77(\mathrm{~m}, 20 \mathrm{H}) ;{ }^{13} \mathrm{C} \mathrm{NMR}\left(\mathrm{CDCl}_{3}\right) \delta-5.8$ $(\mathrm{q}),-5.1(\mathrm{q}), 22.4(\mathrm{t}), 23.8(\mathrm{t}), 31.4(\mathrm{t}), 34.2(\mathrm{t}), 37.3(\mathrm{t}), 37.4$ $(\mathrm{t}), 38.6(\mathrm{t}), 42.8(\mathrm{~d}), 70.2(\mathrm{~s}), 78.4(\mathrm{~s}), 114.5(\mathrm{t}), 127.6(\mathrm{~d}, 2 \mathrm{C})$, 127.7 (d, 2 C), 127.8 (d,2 C), 127.9 (d, 2 C), 129.1 (d), 129.2 (d), 129.3 (d), 129.4 (d), 135.1 (d, 2 C), 135.2 (s), 135.3 (d, 4 C), 135.4 (d, 2 C), 135.5 (s, 2 C), 135.7 (s), 138.2 (d); MS m/ z (rel intensity) $588\left(\mathrm{M}^{+}-2,6\right), 545$ (8), 503 (8), 451 (10), 375 (22), 197 (24), 137 (100); HRMS calcd for $\mathrm{C}_{38} \mathrm{H}_{44} \mathrm{O}_{2} \mathrm{Si}_{2}$ 588.2880, found 588.2878. I somer $\mathbf{c}$ (mixed with isomer b): TLC (EtOAC) hexane (10:90)) $\mathrm{R}_{\mathrm{f}}=0.12 ;{ }^{1} \mathrm{H}$ NMR $\left(\mathrm{CDCl}_{3}\right) \delta 0.42(\mathrm{~s}), 0.50$ (s).

2-[(Tributylstannyl)methyl]cyclopentyl Diphenylmethyl Ether (68). The reaction of $\mathbf{2 1}(494 \mathrm{mg}, 1.68 \mathrm{mmol})$ and $\mathrm{Bu}_{3} \mathrm{SnH}(0.68 \mathrm{~mL}, 2.52 \mathrm{mmol})$ in deoxygenated benzene according to the general procedure afforded cis-68 (85 mg, 9\%), trans-68 (61 mg, 6\%), and a cis/ trans (5:1) mixture of $\mathbf{6 6}(60$ mg, 12\%) and 62 (225 mg, 45\%). cis-68: A light yellow liquid; IR (neat) 2954, 2922, 1584, 1423, 1248, 1115, 1058, 788, 735 $698 \mathrm{~cm}^{-1}$; ${ }^{1} \mathrm{H}$ NMR $\left(\mathrm{CDCl}_{3}\right) \delta 0.65(\mathrm{~s}, 3 \mathrm{H}), 0.65-1.00(\mathrm{~m}, 16$ $\mathrm{H}), 1.15-1.95(\mathrm{~m}, 20 \mathrm{H}), 4.05(\mathrm{br} \mathrm{q}, \mathrm{J}=4.0 \mathrm{~Hz}, 1 \mathrm{H}), 7.25-$ $7.45(\mathrm{~m}, 6 \mathrm{H}), 7.55-7.65(\mathrm{~m}, 4 \mathrm{H}) ;{ }^{13} \mathrm{C} \mathrm{NMR}\left(\mathrm{CDCl}_{3}\right) \delta-2.3$, 9.1, 9.2, 13.7, 21.8, 27.4, 29.3, 31.9, 34.5, 44.0, 78.4, 127.7, 129.5, 134.4, 137.4; MS m/ z (rel intensity) $529\left(\mathrm{M}^{+}-\mathrm{C}_{4} \mathrm{H}_{9}\right.$ 41), 447 (48), 259 (99), 197 (100), 149 (10), 84 (45), 49 (54); HRMS calcd for $\mathrm{C}_{27} \mathrm{H}_{41}$ OSiSn 529.1949; found 529.1946 . trans-68: A light yellow liquid; IR (neat) 2954, 2922, 1584 $1457,1423,1248,1115,789,735,719,698 \mathrm{~cm}^{-1} ;{ }^{1} \mathrm{H}$ NMR $\left(\mathrm{CDCl}_{3}\right) \delta 0.67(\mathrm{~s}, 3 \mathrm{H}), 0.70-1.00(\mathrm{~m}, 16 \mathrm{H}), 1.15-2.10(\mathrm{~m}, 20$ $\mathrm{H}), 3.74(\mathrm{br} q, J=6.0 \mathrm{~Hz}, 1 \mathrm{H}), 7.25-7.45(\mathrm{~m}, 6 \mathrm{H}), 7.55-$ $7.65(\mathrm{~m}, 4 \mathrm{H}) ;{ }^{13} \mathrm{C} \mathrm{NMR}\left(\mathrm{CDCl}_{3}\right) \delta-2.2,9.2,13.4,13.7,21.2$ 27.4, 29.2, 32.3, 33.9, 46.4, 83.6, 127.7, 129.6, 134.4, 137.0; MS $\mathrm{m} / \mathrm{z}$ (rel intensity) $529\left(\mathrm{M}^{+}-\mathrm{C}_{4} \mathrm{H}_{9}, 83\right), 447$ (38), 331 (22), 255 (22), 197 (100), 177 (45), 137 (20), 121 (16), 81 (15); HRMS calcd for $\mathrm{C}_{27} \mathrm{H}_{41} \mathrm{OSiSn} 529.1949$, found 529.1957.

5-Hydroxy-1,5-bis(trimethylsilyl)pentanone (69) and 2,6-Bis(trimethylsilyl)-4,5-dihydro-6H-pyran (75). The reaction of 1,5-bis(trimethylsilyl)-1,5-pentanedione $\mathbf{2 8}$ (200 mg, $0.81 \mathrm{mmol}$ ) with $\mathrm{Sml}_{2}(2 \mathrm{mmol})$ in THF/HMPA at $18^{\circ} \mathrm{C}$ for 12 h gave 69 (20 mg, 10\%) and 75 (112 mg, 61\%). Compound 69 was unstable and converted to 75 on standing. 69: An oil; TLC (EtOAc/hexane (5:95)) $\mathrm{R}_{\mathrm{f}}=0.1 ;{ }^{1} \mathrm{H}$ NMR $\left(\mathrm{CDCl}_{3}\right) \delta 0.16$ $(\mathrm{s}, 18 \mathrm{H}), 1.65-1.85(\mathrm{~m}, 4 \mathrm{H}), 2.56(\mathrm{t}, \mathrm{J}=7.0 \mathrm{~Hz}, 2 \mathrm{H}), 3.71(\mathrm{t}$, $\mathrm{J}=6.6 \mathrm{~Hz}, 1 \mathrm{H})$. 75: An oil; TLC (EtOAc/hexane $(5: 95)) \mathrm{R}_{\mathrm{f}}=$ 0.25 ; IR (neat) 2958, 2917, 1619, 1248, 1082, 1038, $1011 \mathrm{~cm}^{-1}$; ${ }^{1} \mathrm{H} \mathrm{NMR}\left(\mathrm{CDCl}_{3}\right) \delta 0.01(\mathrm{~s}, 9 \mathrm{H}), 0.03(\mathrm{~s}, 9 \mathrm{H}), 1.62-1.78(\mathrm{~m}$, $2 \mathrm{H}), 1.91-2.04(\mathrm{~m}, 2 \mathrm{H}), 3.40(\mathrm{dd}, \mathrm{J}=11.1,3.2 \mathrm{~Hz}, 1 \mathrm{H})$, 4.90-4.94 (m, $1 \mathrm{H}) ;{ }^{13} \mathrm{C} N M R\left(\mathrm{CDCl}_{3}\right) \delta-4.1(\mathrm{q}, 3 \mathrm{C}),-2.5(\mathrm{q}$, 3 C), 21.3 (t), 23.4 (t), 69.1 (d), 109.2 (d), 162.0 (s); MS m/ z (rel intensity) $228\left(\mathrm{M}^{+}, 10\right), 171$ (2), 155 (100), 147 (31), 116 (18), 101 (12), 73 (60); HRMS calcd for $\mathrm{C}_{11} \mathrm{H}_{24} \mathrm{OSi}_{2} 228.1366$, found 228.1368 .

6-Hydroxy-1,6-bis(trimethylsilyl)hexanone (70), 1,6Bis(trimethylsilyl)-1,6-hexanediol (73), and 1-(Trimethylsilyl)-2-[(trimethylsilyl)carbonyl]cyclopentanol (77). The reaction of 1,6-bis(trimethylsilyl)-1,6-hexanedione 30 (150 $\mathrm{mg}, 0.77 \mathrm{mmol})$ with $\mathrm{Sml}_{2}(2 \mathrm{mmol})$ in $\mathrm{THF}$ at $20{ }^{\circ} \mathrm{C}$ for $1 \mathrm{~h}$ gave 70 (25 mg, 13\%), 73 (20 mg, 9\%), and 77 (92 mg, 46\%). 70: An oil; TLC (EtOAc/hexane (15:85)) $\mathrm{R}_{\mathrm{f}}=0.28$; IR (neat) $3400,2953,2857,1640,1247,841,750 \mathrm{~cm}^{-1} ;{ }^{1} \mathrm{H} \mathrm{NMR}\left(\mathrm{CDCl}_{3}\right)$ $\delta 0.00(\mathrm{~s}, 9 \mathrm{H}), 0.09(\mathrm{~s}, 9 \mathrm{H}), 1.25-1.57(\mathrm{~m}, 7 \mathrm{H}), 2.59(\mathrm{t}, \mathrm{J}=$ $6.6 \mathrm{~Hz}, 2 \mathrm{H}), 3.27(\mathrm{dd}, \mathrm{J}=9.1,4.0 \mathrm{~Hz}, 1 \mathrm{H}) ;{ }^{13} \mathrm{C} \mathrm{NMR}\left(\mathrm{CDCl}_{3}\right)$ $\delta-3.9(\mathrm{q}, 3 \mathrm{C}),-3.1(\mathrm{q}, 3 \mathrm{C}), 21.6(\mathrm{t}), 26.3(\mathrm{t}), 33.1(\mathrm{t}), 48.2(\mathrm{t})$, 65.5 (d), 248.6 (s); MS m/ z (rel intensity) $242\left(\mathrm{M}^{+}-18,6\right)$, 169 (58), 147 (30), 129 (20), 111 (2), 85 (1), 73 (100). 73: Two isomers, solid; $\mathrm{mp} 69-73^{\circ} \mathrm{C}$; TLC (EtOAc/hexane (15:85)) $\mathrm{R}_{\mathrm{f}}$ $=0.1$; IR (KBr) 3413, 2912, 1242, 1057, 1011, 916, $837 \mathrm{~cm}^{-1}$; ${ }^{1} \mathrm{H} N M R\left(\mathrm{CDCl}_{3}\right) \delta 0.00(\mathrm{~s}, 18 \mathrm{H}), 1.19-1.50(\mathrm{~m}, 10 \mathrm{H}), 3.26$ $(\mathrm{t}, \mathrm{J}=6.9 \mathrm{~Hz}, 2 \mathrm{H}) ;{ }^{13} \mathrm{C} \mathrm{NMR}\left(\mathrm{CDCl}_{3}\right) \delta-3.9(\mathrm{q}, 12 \mathrm{C}), 26.4(\mathrm{t}$, 2 C), 26.7 (t, 2 C), $33.3(t, 2 \mathrm{C}), 33.4(\mathrm{t}, 2 \mathrm{C}), 65.8(\mathrm{~d}, 2 \mathrm{C}), 66.0$ (d, 2 C); MS m/ z (rel intensity) $263\left(M^{+}+1,15\right), 245$ (8), 226 (12), 171 (10), 147 (22), 136 (18), 73 (100); HRMS calcd for $\mathrm{C}_{12} \mathrm{H}_{29} \mathrm{O}_{2} \mathrm{Si}_{2}$ 261.1706, found 261.1694. 77: An oil; TLC (EtOAc/hexane (15:85)) $\mathrm{R}_{\mathrm{f}}=0.45$; IR (neat) 3400, 2957, 2901, $1620,1249,840,750 \mathrm{~cm}^{-1}$; ${ }^{1} \mathrm{H}$ NMR $\left(\mathrm{CDCl}_{3}\right) \delta-0.05(\mathrm{~s}, 9 \mathrm{H})$, $0.18(\mathrm{~s}, 9 \mathrm{H}), 1.51-1.80(\mathrm{~m}, 4 \mathrm{H}), 1.94-2.05(\mathrm{~m}, 2 \mathrm{H}), 3.11$ $(\mathrm{dd}, \mathrm{J}=10.6,8.1 \mathrm{~Hz}, 1 \mathrm{H}), 4.13-4.94(\mathrm{~s}, 1 \mathrm{H}) ;{ }^{13} \mathrm{C} \mathrm{NMR}$ (acetone- $\left.\mathrm{d}_{6}\right) \delta-3.2(\mathrm{q}, 3 \mathrm{C}),-2.9(\mathrm{q}, 3 \mathrm{C}), 23.6(\mathrm{t}), 28.6(\mathrm{t})$, $38.2(\mathrm{t}), 61.0(\mathrm{~d}), 77.7(\mathrm{~s}), 257.3(\mathrm{~s}) ; \mathrm{MS} \mathrm{m} / \mathrm{z}$ (rel intensity) 258 $\left(\mathrm{M}^{+}, 10\right), 230$ (2), 217 (4), 157 (10), 147 (16), 117 (2), 73 (100); HRMS calcd for $\mathrm{C}_{12} \mathrm{H}_{26} \mathrm{O}_{2} \mathrm{Si}_{2} 258.1471$, found 258.1487 .

7-Hydroxy-1,7-bis(trimethylsilyl)octanone (71) and 1,8Bis(trimethylsilyl)-1,8-hexanediol (74). The reaction of 1,8-bis(trimethylsilyl)-1,8-hexanedione (31) (200 mg, $0.69 \mathrm{mmol}$ ) with $\mathrm{Sml}_{2}$ (2 mmol) in THF for $1 \mathrm{~h}$ gave 71 (105 mg, 53\%), and 74 (72 mg, 36\%). 71: An oil; TLC (EtOAc/hexane (1:90)) $\mathrm{R}_{\mathrm{f}}=0.25$; IR (neat) 3438, 2926, 2853, 1633, 1245, 841, 750 $\mathrm{cm}^{-1} ;{ }^{1} \mathrm{H} N M R\left(\mathrm{CDCl}_{3}\right) \delta 0.00(\mathrm{~s}, 9 \mathrm{H}), 0.16(\mathrm{~s}, 9 \mathrm{H}), 1.22-1.50$ $(\mathrm{m}, 11 \mathrm{H}), 2.55(\mathrm{t}, \mathrm{J}=7.2 \mathrm{~Hz}, 2 \mathrm{H}), 3.25(\mathrm{t}, \mathrm{J}=6.9 \mathrm{~Hz}, 1 \mathrm{H})$; ${ }^{13} \mathrm{C} N M R\left(\mathrm{CDCl}_{3}\right) \delta-3.9(\mathrm{q}, 3 \mathrm{C}),-3.1(\mathrm{q}, 3 \mathrm{C}), 22.0(\mathrm{t}), 26.6$ $(\mathrm{t}), 29.3(\mathrm{t}), 29.4(\mathrm{t}), 33.4(\mathrm{t}), 48.4(\mathrm{t}), 65.9(\mathrm{~d}), 248.6(\mathrm{~s}) ; \mathrm{MS}$ $\mathrm{m} / \mathrm{z}$ (rel intensity) $243\left(\mathrm{M}^{+}-45,1\right), 217(2), 185$ (3), 165 (5), 147 (13), 129 (20), 73 (100); HRMS calcd for $\mathrm{C}_{14} \mathrm{H}_{31} \mathrm{O}_{2} \mathrm{Si}_{2}$ 287.1863, found 287.1864. 74: Two isomers, solid; $\mathrm{mp} 79-$ 
$84^{\circ} \mathrm{C}$; TLC (EtOAc/hexane (10:90)) $\mathrm{R}_{\mathrm{f}}=0.15$; IR (KBr) 3358, 2923, 2850, 1372, 1244, 1054, $910 \mathrm{~cm}^{-1} ;{ }^{1} \mathrm{H} \mathrm{NMR}\left(\mathrm{CDCl}_{3}\right) \delta$ $0.00(\mathrm{~s}, 18 \mathrm{H}), 1.21-1.47(\mathrm{~m}, 14 \mathrm{H}), 3.25(\mathrm{t}, \mathrm{J}=6.6 \mathrm{~Hz}, 2 \mathrm{H})$; ${ }^{13} \mathrm{C} \mathrm{NMR}\left(\mathrm{CDCl}_{3}\right) \delta-3.9(\mathrm{q}, 12 \mathrm{C}), 26.7(\mathrm{t}, 2 \mathrm{C}), 26.8(\mathrm{t}, 2 \mathrm{C})$, 29.4 (t, 2 C), 29.5 (t, 2 C), $33.5(t, 2$ C), 65.9 (d, 4 C). FAB-MS m/ z (rel intensity) $291\left(\mathrm{M}^{+}+1,20\right), 273$ (10), 225 (30), 154 (8), 136 (28), 129 (12), 73 (100); HRMS calcd for $\mathrm{C}_{14} \mathrm{H}_{32} \mathrm{OSi}_{2}$ 272.1992, found 272.1999 .

1,5-Bis(diphenylmethylsilyl)-1,5-pentanediol (72) and 2,6-Bis(diphenylmethylsilyl)-4,5-dihydro-6H-pyran (76). The reaction of $\mathbf{2 9}(230 \mathrm{mg}, 0.47 \mathrm{mmol})$ and $\mathrm{Bu}_{3} \mathrm{SnH}(0.25 \mathrm{~mL}$, $0.94 \mathrm{mmol})$ in deoxygenated benzene $(10 \mathrm{~mL})$ according to the general procedure gave $\mathbf{7 6}$ (116 $\mathrm{mg}, 52 \%$ ) and a diastereomeric mixture of 72 (28 mg, 12\%). 72: A white solid; mp 103-106 ${ }^{\circ} \mathrm{C}$; IR $\left(\mathrm{CH}_{2} \mathrm{Cl}_{2}\right)$ 3587, 3067, 2926, 1423, 1363, 1110, 1042, 996, $789 \mathrm{~cm}^{-1} ;{ }^{1} \mathrm{H}$ NMR $\left(\mathrm{CDCl}_{3}\right) \delta 0.57(\mathrm{~s}, 6 \mathrm{H}),, 1.10-1.70(\mathrm{~m}, 8$ $\mathrm{H}), 3.84(\mathrm{~m}, 2 \mathrm{H}), 7.25-7.40(\mathrm{~m}, 12 \mathrm{H}), 7.40-7.55(\mathrm{~m}, 8 \mathrm{H})$; ${ }^{13} \mathrm{C} \mathrm{NMR}\left(\mathrm{CDCl}_{3}\right) \delta-6.8,-6.7,24.2,24.4,32.6,33.3,64.2,64.6$, $127.9,129.5,129.6,134.6,134.9,135.0$. Anal. Calcd for $\mathrm{C}_{31} \mathrm{H}_{36} \mathrm{O}_{2} \mathrm{Si}_{2}$ : C, 74.95; $\mathrm{H}, 7.30$. Found: $\mathrm{C}, 74.43 ; \mathrm{H}, 7.17 .76$ : A light yellow oil; IR (neat) 3064, 3043, 1612, 1424, 1251, 1149, $1112,1080,1008,909,820 \mathrm{~cm}^{-1}$; $1 \mathrm{H}$ NMR $\left(\mathrm{CDCl}_{3}\right) \delta 0.56(\mathrm{~s}, 3$ $\mathrm{H}), 0.62(\mathrm{~s}, 3 \mathrm{H}), 1.82-2.20(\mathrm{~m}, 4 \mathrm{H}), 4.10(\mathrm{t}, \mathrm{J}=7 \mathrm{~Hz}, 1 \mathrm{H})$, 5.10-5.18 (m, 1 H), 7.20-7.49 (m, $12 \mathrm{H}), 7.49-7.70(\mathrm{~m}, 8 \mathrm{H})$; ${ }^{13} \mathrm{C} \mathrm{NMR}\left(\mathrm{CDCl}_{3}\right) \delta-6.6,-5.0,21.6,23.6,68.9,114.2,127.6$, $127.7,129.2,129.3,134.9,135.1,135.2,135.5,158.5 ; \mathrm{MS} \mathrm{m} / \mathrm{z}$ (rel intensity) $476\left(\mathrm{M}^{+}, 5\right), 333$ (16), 319 (6), 279 (100), 255 (10), 197 (74), 137 (6); HRMS calcd for $\mathrm{C}_{31} \mathrm{H}_{32} \mathrm{OSi}_{2} 476.1991$, found 476.1960 .

3-Hydroxy-3-(trimethylsilyl)cyclohexanone (78). The reaction of 1-(trimethylsilyl)-1,5-hexanedione (33) (80 mg, 0.43 $\mathrm{mmol})$ with $\mathrm{Sml}_{2}(0.43 \mathrm{mmol})$ in $\mathrm{THF}$ at $22^{\circ} \mathrm{C}$ for $10 \mathrm{~min}$ gave 78 (45 mg, 56\%). An oil; TLC (EtOAc/hexane (20:80)) $\mathrm{R}_{\mathrm{f}}=$ 0.22 ; IR (neat) 3436, 2948, 1704, 1247, 1111, 940, $839 \mathrm{~cm}^{-1}$; ${ }^{1} \mathrm{H}$ NMR $\left(\mathrm{CDCl}_{3}\right) \delta 0.04(\mathrm{~s}, 9 \mathrm{H}), 1.07-2.01(\mathrm{~m}, 4 \mathrm{H}), 2.21-$ $2.47(\mathrm{~m}, 4 \mathrm{H}) ;{ }^{13} \mathrm{C}$ NMR (acetone- $\left.\mathrm{d}_{6}\right) \delta-4.5(\mathrm{q}, 3 \mathrm{C}), 22.1(\mathrm{t})$, $32.1(\mathrm{t}), 41.8(\mathrm{t}), 49.3(\mathrm{t}), 70.3(\mathrm{~s}), 210(\mathrm{~s}) ; \mathrm{MS} \mathrm{m} / \mathrm{z}$ (rel intensity) $186\left(\mathrm{M}^{+}, 6\right), 185(20), 169(10), 158$ (15), 143 (55), 125 (18), 73 (100); HRMS calcd for $\mathrm{C}_{9} \mathrm{H}_{18} \mathrm{O}_{2} \mathrm{Si} 186.1076$, found 186.1073.

6-(Trimethylsilyl)-3,4,5,6-tetrahydropyran-2-one (79). The mixture of 1-(trimethylsilyl)-1,5-pentanedione (37) and the dihydropyran derivative 38 (85 $\mathrm{mg}, 0.49 \mathrm{mmol} ; \mathbf{3 7 / 3 8}=5 / 1)$ was treated with $\mathrm{Sml}_{2}(0.49 \mathrm{mmol})$ in $\mathrm{THF} / \mathrm{MeOH}(1 \mathrm{mmol})$ at $28{ }^{\circ} \mathrm{C}$ for $5 \mathrm{~min}$ gave 79 (67 mg, 79\%). An oil; TLC (EtOAd hexane (20:80)) $R_{f}=0.28$; IR (KBr) 2954, 2856, 1730, 1249, $1179,1034,842 \mathrm{~cm}^{-1} ;{ }^{1} \mathrm{H}$ NMR $\left(\mathrm{CDCl}_{3}\right) \delta 0.06(\mathrm{~s}, 9 \mathrm{H}), 1.60-$ $1.94(\mathrm{~m}, 4 \mathrm{H}), 2.34-2.61(\mathrm{~m}, 2 \mathrm{H}), 4.04(\mathrm{dd}, \mathrm{J}=12.1,3.6 \mathrm{~Hz}$, $1 \mathrm{H}) ;{ }^{13} \mathrm{C} \mathrm{NMR}\left(\mathrm{CDCl}_{3}\right) \delta-4.3(\mathrm{q}, 3 \mathrm{C}), 20.3(\mathrm{t}), 23.3(\mathrm{t}), 29.6$ (t), $75.3(\mathrm{~d}), 173.2(\mathrm{~s}) ; \mathrm{MS} \mathrm{m} / \mathrm{z}$ (rel intensity) $157\left(\mathrm{M}^{+}-15\right.$, 48), 143 (18), 129 (17), 116 (100), 101 (65), 75 (70), 73 (52); HRMS calcd for $\mathrm{C}_{8} \mathrm{H}_{16} \mathrm{O}_{2} \mathrm{Si} 172.0920$, found 172.0911 .

Methyl 6-Hydroxy-6-(trimethylsilyl)hexanoate (80). To a solution of $\mathrm{Sml} / \mathrm{THF} / \mathrm{M} \mathrm{eOH}(0.55 \mathrm{mmol} / 5.5 \mathrm{~mL} / 1 \mathrm{mmol})$ was added 1-(trimethylsi lyl)-1,6-hexanedione (47) (93 mg, 0.5 $\mathrm{mmol})$ in THF ( $1 \mathrm{~mL})$ in one portion at $30^{\circ} \mathrm{C}$ under Ar. The reaction was stirred for $30 \mathrm{~min}$ and filtered. The filtrate was concentrated, and the residue was purified by silica gel chromatography with elution of EtOAc/hexane (15:85) to give 80 (63 mg, 62\%). An oil; TLC (EtOAc/hexane (15:85)) $R_{f}=0.1$; IR (neat) 3442, 2950, 1733, 1431, 1244, 1199, $838 \mathrm{~cm}^{-1} ;{ }^{1} \mathrm{H}$ NMR $\left(\mathrm{CDCl}_{3}\right) \delta 0.00(\mathrm{~s}, 9 \mathrm{H}), 1.21-1.67(\mathrm{~m}, 6 \mathrm{H}), 2.29(\mathrm{t}, \mathrm{J}=$ $7.2 \mathrm{~Hz}, 2 \mathrm{H}$ ), $3.27(\mathrm{t}, \mathrm{J}=7.0 \mathrm{~Hz}, 1 \mathrm{H}), 3.62(\mathrm{~s}, 3 \mathrm{H}) ;{ }^{13} \mathrm{C} N M R$ $\left(\mathrm{CDCl}_{3}\right) \delta-3.9(\mathrm{q}, 3 \mathrm{C}), 24.6(\mathrm{t}), 26.2(\mathrm{t}), 32.9(\mathrm{t}), 33.9(\mathrm{t}), 51.4$ (q), 65.6 (d), 174.2 (s); MS m/ z (rel intensity) 203 (M+ - 15, 21), 172 (11), 171 (82), 143 (18), 129 (13), 89 (15), 73 (100); HRMS calcd for $\mathrm{C}_{9} \mathrm{H}_{19} \mathrm{O}_{3} \mathrm{Si} 203.1104$, found 203.1105 .
1,12-Bis(trimethylsilyl)-6,7-dihydroxydodecane-1,12dione (81). To a solution of 1-(trimethylsilyl)-1,6-hexanedione (47) $(180 \mathrm{mg}, 0.96 \mathrm{mmol})$ and t-BuOH $(0.19 \mathrm{~mL}, 2 \mathrm{mmol})$ in THF $(5 \mathrm{~mL})$ was added $0.1 \mathrm{M}$ solution of $\mathrm{Sml} / 2 / \mathrm{THF}(0.9 \mathrm{mmol} / 9$ $\mathrm{mL}$ ) at $-78^{\circ} \mathrm{C}$ under $\mathrm{Ar}$. The resulting sol ution was warmed to $32{ }^{\circ} \mathrm{C}$ and stirred for $2 \mathrm{~h}$. The reaction was quenched by addition of $\mathrm{Et}_{2} \mathrm{O}(20 \mathrm{~mL})$ and filtered. The filtrate was concentrated, and the residue was purified by silica gel chromatography with elution of EtOAc/hexane (15:85) to give 81 (121 mg, 67\%) as a mixture of two diastereomers (3:1). An oil; TLC (EtOAc/hexane $(15: 85)) \mathrm{R}_{\mathrm{f}}=0.22$; IR (neat) 3442 , 2938, 1632, 1247, 1167, 1082, $839 \mathrm{~cm}^{-1} ;{ }^{1} \mathrm{H}$ NMR $\left(\mathrm{CDCl}_{3}\right)$ (major) $\delta 0.12(\mathrm{~s}, 9 \mathrm{H}), 0.16(\mathrm{~s}, 9 \mathrm{H}), 1.23-1.89(\mathrm{~m}, 12 \mathrm{H}), 2.61$ $(\mathrm{t}, \mathrm{J}=7.0 \mathrm{~Hz}, 4 \mathrm{H}), 3.60-3.75(\mathrm{~m}, 2 \mathrm{H}) ; \mathrm{MS} \mathrm{m} / \mathrm{z}$ (rel intensity) $374\left(\mathrm{M}^{+}, 8\right), 284$ (4), 259 (4), 217 (4), 187 (24), 171 (100), 73 (90); HRMS calcd for $\mathrm{C}_{18} \mathrm{H}_{38} \mathrm{O}_{4} \mathrm{Si}_{2} 374.2308$, found 374.2309 .

2-(Dimethylphenylsilyloxy)cyclopentanol (82) and cis1,2-Cyclopentanediol (83). The reaction of $\mathbf{4 6}$ (335 mg, 1.43 $\mathrm{mmol})$ and $\mathrm{Bu}_{3} \mathrm{SnH}(0.58 \mathrm{~mL}, 2.1 \mathrm{mmol})$ in deoxygenated benzene $(14 \mathrm{~mL})$ according to the general procedure afforded cis-82 (70 mg, 21\%), trans-82 (61 mg, 18\%), and cis-83 (47 mg, $32 \%$ ) which was identical to a commercially available authentic sample. cis-82: IR (neat) 3546, 3047, 2959, 2901, 1423, 1250. $1116,1050,994,890,829,786,740,700 \mathrm{~cm}^{-1} ;{ }^{1} \mathrm{H} \mathrm{NMR}\left(\mathrm{CDCl}_{3}\right)$ $\delta 0.41(\mathrm{~s}, 3 \mathrm{H}), 0.42(\mathrm{~s}, 3 \mathrm{H}), 1.30-1.45(\mathrm{~m}, 1 \mathrm{H}), 1.55-1.85$ $(\mathrm{m}, 6 \mathrm{H}), 2.63(\mathrm{~d}, \mathrm{~J}=4.2 \mathrm{~Hz}, 1 \mathrm{H}), 3.88$ (quintet, $\mathrm{J}=4.2 \mathrm{~Hz}$, $1 \mathrm{H}), 4.01(\mathrm{td}, \mathrm{J}=7.0,4.2 \mathrm{~Hz}, 1 \mathrm{H}), 7.35-7.45(\mathrm{~m}, 3 \mathrm{H}), 7.55-$ $7.65(\mathrm{~m}, 4 \mathrm{H}) .{ }^{13} \mathrm{C} N M R\left(\mathrm{CDCl}_{3}\right) \delta-1.4,-1.3,19.8,30.7,31.0$, 73.4, 75.4, 127.9, 129.7, 133.3, 137.5. Anal. Calcd for $\mathrm{C}_{13} \mathrm{H}_{20} \mathrm{O}_{2-}$ Si: C, 66.05; $\mathrm{H}, 8.53$. Found: $\mathrm{C}, 65.51 ; \mathrm{H}, 8.64$. trans-82: IR (neat) 3367, 2957, 1423, 1249, 1116, 1043, 990, 876, 828, $784,740,699 \mathrm{~cm}^{-1}$; ${ }^{1} \mathrm{H}$ NMR $\left(\mathrm{CDCl}_{3}\right) \delta 0.39(\mathrm{~s}, 6 \mathrm{H}), 1.30$ $2.05(\mathrm{~m}, 7 \mathrm{H}), 3.86-4.02(\mathrm{~m}, 2 \mathrm{H}), 7.30-7.40(\mathrm{~m}, 3 \mathrm{H}), 7.35-$ $7.65(\mathrm{~m}, 2 \mathrm{H}) .{ }^{13} \mathrm{C}$ NMR $\left(\mathrm{CDCl}_{3}\right) \delta-1.4,-1.1,19.8,31.1,31.9$ 79.4, 80.2, 127.9, 129.6, 133.4, 138.3. Anal. Calcd for $\mathrm{C}_{13} \mathrm{H}_{20} \mathrm{O}_{2-}$ Si: C, 66.05; H, 8.53. Found: C, 66.04; H, 8.83.

7-Hydroxy-7-(dimethylphenylsilyl)heptanal (84). The reaction of $48(262 \mathrm{mg}, 1.00 \mathrm{mmol})$ and $\mathrm{Bu}_{3} \mathrm{SnH}(0.269 \mathrm{~mL}$, $1.00 \mathrm{mmol}$ ) in deoxygenated benzene $(5 \mathrm{~mL})$ according to the general procedure gave $\mathbf{8 4}(100 \mathrm{mg}, 38 \%)$ as a light yellow liquid. IR (neat) 3458, 2928, 2854, 1717, 1244, 1110, 814, 701 $\mathrm{cm}^{-1}$; ${ }^{1} \mathrm{H}$ NMR $\left(\mathrm{CDCl}_{3}\right) \delta 0.31(\mathrm{~s}, 3 \mathrm{H}), 0.32$, (s, $\left.3 \mathrm{H}\right), 1.05-$ $1.65(\mathrm{~m}, 8 \mathrm{H}), 2.37(\mathrm{td}, \mathrm{J}=9.0,2.0 \mathrm{~Hz}, 2 \mathrm{H}), 3.47(\mathrm{t}, \mathrm{J}=7.0$ $\mathrm{Hz}, 1 \mathrm{H}), 7.25-7.45(\mathrm{~m}, 3 \mathrm{H}), 7.45-7.65(\mathrm{~m}, 2 \mathrm{H}), 9.71(\mathrm{t}, \mathrm{J}=$ $2.0 \mathrm{~Hz}, 1 \mathrm{H}) ;{ }^{13} \mathrm{C} \mathrm{NMR}\left(\mathrm{CDCl}_{3}\right) \delta-5.7,-5.5,22.0,26.5,28.9$, 33.1, 43.7, 65.3, 127.9, 129.3, 134,0, 136.6, 202.7; MS m/ z (rel intensity) $263\left(\mathrm{M}^{+}-1,1\right), 249\left(\mathrm{M}^{+}-\mathrm{CH}_{3}, 0.5\right), 247(5), 185$ (10), 165 (5), 135 (100), 129 (8), 91 (8), 81 (8), 75 (24), 55 (11); HRMS calcd for $\mathrm{C}_{14} \mathrm{H}_{21} \mathrm{O}_{2} \mathrm{Si} 249.1331$, found 249.1321 .

Acknowledgment. We thank the National Science Council of the Republic of China for financial support (Grants NSC84-2113-M-002-010 and NSC84-2113-M002-006). Gratitude is due to Sheng-Yueh Chang, J enSen Pan, and J iuen-Ahn Sieh for providing procedures or preparations of compounds 6, 15, 16, and $\mathbf{2 1 .}$

Supporting Information Available: NMR spectra (66 pages) of new compounds. This material is contained in libraries on microfiche, immediately follows this article in the microfilm version of the journal, and can be ordered from the ACS; ordering information is given on any current masthead page.

J O951980M 